\title{
Coastal landforms caused by deposition and erosion along the shoreline between Punta Brava and Punta Betín, Santa Marta, Colombian Caribbean
}

\author{
Víctor H. Vargas-T. ${ }^{1}$, Eliécer Uribe-P. ${ }^{1}$, Carlos A. Ríos-R. ${ }^{1, *}$, Oscar M. Castellanos-A. ${ }^{2}$ \\ ${ }^{1}$ Grupo de Investigación en Geología Básica y Aplicada (GIGBA), Escuela de Geología, Universidad Industrial de Santander, Colombia \\ ${ }^{2}$ Grupo de Investigación en Geofísica y Geología (PANGEA), Programa de Geología, Universidad de Pamplona, Colombia
}

\begin{abstract}
Coasts are natural dynamic systems that are constantly changing. Several factors, such as sea level change, sediment availability and coastal processes strongly influence the evolution of the coastal landscape. However, the tectonic setting of the coast and the rate of sea level rise can also be important factors to consider. Coastal landforms are a consequence of the simultaneous operation of erosion, transportation and deposition processes and have evolved over a geologically short time, with several of them being almost exclusively the result of the action of ocean waves. The world's most spectacular and dramatic erosional landforms are due to wave action, whereas the reduction of wave energy created deposition landforms. This paper presents an analysis of the coastal landforms caused by deposition and erosion along the shoreline in the sector between Punta Brava and Punta Betín, Santa Marta region, Colombian Caribbean. On the other hand, it is a contribution to the geological knowledge of the Geotectonic Province of Santa Marta and emerges as an alternative solution to various problems. It also promotes research on this region regarding other factors such as the increasing marine activity, population in coastal areas, development of tourism, as well as a series of geological evolutionary processes that reflect in coastal morphology. Coastal landforms are valuable environmental, aesthetic, and recreational resources that are subject to natural processes as well as to the effects of human activities. The results of this study can provide a sound basis for sustainable planning and management of the territory. (C) 2016. Acad. Colomb. Cienc. Ex. Fis. Nat.
\end{abstract}

Key words: Coastal landforms; Santa Marta; Geotectonic province; Colombian Caribbean; Evolutionary processes.

Geoformas costeras causadas por depositación y erosión a lo largo de la línea costera entre Punta Brava y Punta Betín, Santa Marta, Caribe Colombiano

\section{Resumen}

Las costas son sistemas naturales dinámicos que cambian constantemente. La evolución del paisaje costero está fuertemente influenciada por varios factores, tales como el cambio del nivel del mar, la disponibilidad de sedimento y los procesos costeros. Sin embargo, la configuración tectónica de la costa y la tasa de aumento del nivel del mar pueden ser también factores importantes a tener en cuenta. Las geoformas costeras son una consecuencia de la operación simultánea de procesos de erosión, transporte y deposición y han evolucionado durante un periodo de tiempo geológicamente corto; varios de dichos procesos han sido el resultado casi exclusivo de la acción de las olas del mar. Las geoformas costeras de erosión más espectaculares y dramáticas del mundo se deben a la acción del oleaje, mientras que las formas deposicionales se producen por la reducción de la energía de las olas. En este trabajo se presenta un análisis de las geoformas costeras entre Punta Brava y Punta Betín, en Santa Marta, Caribe colombiano. Por otra parte, es una contribución al conocimiento geológico de la Provincia Geotectónica de Santa Marta, que surge como una alternativa de solución a problemas y promueve la investigación en la costa del Caribe colombiano en respuesta al aumento de la actividad marítima, la población en las zonas costeras, el desarrollo del turismo, así como una serie de procesos geológicos evolutivos que se reflejan en su morfología costera. Las geoformas costeras son valiosos recursos ambientales, estéticos y recreativos que están sujetos a procesos naturales, así como al efecto de las actividades humanas. Los resultados de este estudio pueden proporcionar una base sólida en la planificación y gestión sostenible del territorio. (C) 2016. Acad. Colomb. Cienc. Ex. Fis. Nat.

Palabras clave: Geoformas costeras; Provincia geotectónica; Santa Marta; Caribe colombiano; Procesos evolutivos.

\section{Introduction}

Several processes occurring in the atmosphere on the earth's surface, in the ocean and on the land surface are responsible for shaping the coastline; the interaction between these three different sets of processes makes the coastline an extremely dynamic area with constant sediment movement, creating new morphological features and changing positions (Davidson-Arnott, 2010; Absalonsen \& Dean, 2011). Coasts mark the area where dry land meets oceans or other

*Corresponding autor:

Carlos A. Ríos R., carios@uis.edu.co

Received: June 27, 2016

Accepted: November 01, 2016 
large bodies of water. As they are subject to constant change due to the conflicting processes of erosion (the gradual wearing away of Earth surfaces through the action of wind and water) and of deposition (the accumulation and building up of natural materials), which makes them one of the most beautiful and inspiring landscapes on the planet. However, coastal areas are also one of the most vulnerable environments (McFadden, et al., 2007), and one of the most dynamic as a result of the combined action of erosion and sedimentation, conditioned in its turn by the interaction of climatic, tectonic and marine effects as well as by human action. The coast provides significant benefits for the national industry given the variety of unique ecosystems it has, but the implemention of ambitious development plans introduce major modifications that affect the coastal area. In this sense, development activities have had adverse effects on the protection of the natural heritage and on the quality of the coastal environment. Geomorphic variations in coastal environments are described and classified in numerous ways, and this reflects the inherent complexity of shorelines and the many applications of such classifications (Shipman, 2008). The choice of a classification depends on its intended purpose (Cooper \& MacLoughlin, 1998; Fairbridge, 2004; Finkl, 2004), and it is unlikely that a single system address all possible concerns, which may range from improved scientific understanding of shoreline changes over time to management needs for oil-spill response or restoration planning. On the other hand, geomorphological classifications may emphasize the shape of landforms (morphology) or the processes that form them (genesis), although they are inherently linked (Davies, 1977). Coastal landforms are frequently categorized as either erosional or depositional, but this depends on both the temporal and spatial scales of analysis (Shipman, 2008). Therefore, studies of coastal areas are important, as they are dynamic and amenable to changes due to terrestrial and marine processes, as well as human activities (Lalbiakzuali, et al., 2013). The study area is part of the northwestern foothills of the Sierra Nevada de Santa Marta Massif (SNSMM), which constitutes an isolated triangular-shaped range on the northern Colombian Caribbean representing an uplifted region (Figure 1). It comprises a coastal strip extending from Punta Brava (south) to Punta Betín (north) along approximately $20 \mathrm{~km}$ of coastal line $2 \mathrm{~km}$ wide at the coast (beaches and cliffs). Coastal erosion represents a serious socioeconomic problem at the local level, as it affects the residents of coastal towns and the tourism industry, but also at the regional level, influencing potential regional progress due to significant economic losses, social problems and ecological damage (Aiello, et al., 2013). There are examples on the Caribbean coasts on how it is possible to protect them by carrying out infrastructure works to ward off the onslaught caused by marine dynamics and avoid erosion problems that significantly affect production activities and populations. However, the construction of hard structures along the coast both for the development of ports and harbours and for protecting the coast from erosion, significantly modifies the shoreline and the erosion/accretion trend (Mohanty, et al., 2015); additionally, it must be noted that the wave regime is the main factor generating coastal processes. The aim of this study was to determine the coastal geomorphological features in the idea of contributing to a better understanding that may help planners in policy design for a sustainable development and management of the coastal region and its resources. On the other hand, it is a contribution to the geological knowledge of the Geotectonic Province of Santa Marta (GPSM) and promotes research regarding the shoreline and the effect of increasing marine activity and population, the strengthening of tourism industry in the study area and a series of geological evolutionary processes reflecting on the coastal morphology.

Regional setting. Many studies on the Colombian Andes have focused on the SNSMM (Radelli, 1962; Campbell, 1965; Tschanz, et al., 1969, 1974; Doolan, 1970; Irving, 1971; MacDonald, et al., 1971; Kellogg, 1984; RestrepoPace, et al., 1997; Ordóñez-Cardona, et al., 2002; Cordani, et al., 2005; Cardona, et al., 2006, 2010; Mejía, et al., 2008; Montes, et al., 2010), especially on tectonic and stratigraphical aspects. Faults, tertiary basins and the structural depression of the Cesar and Ranchería rivers surround this ancient massif revealing a complex geology caused by three major orogenies and at least three periods of faulting. Two major fault systems of great significance in the tectonics of our country and continent, the sinistral Santa Marta - Bucaramanga fault and the dextral Oca fault, affected this massif. The Oca fault (Irving, 1971), the Santa Marta - Bucaramanga fault (Campbell, 1965), the Cerrejón thrust sheet (Kellogg, 1984) and the Romeral suture (Montes, et al., 2010) are the major structures bounding the massif. It is mainly composed of crystalline rocks and comprises three geotectonic provinces (Sierra Nevada, Sevilla and Santa Marta), with a defined outboard younging pattern from east to west. The southeastern and oldest Geotectonic Province of Sierra Nevada (GPSN) includes ca. 1.0-1.2 Ga high-grade metamorphic rocks (granulites, gneisses and amphibolites) affected during the Grenvillian orogenic event (Restrepo-Pace, et al., 1997; Ordóñez-Cardona, et al., 2002). Jurassic plutons and volcanites intrude and cover these metamorphic rocks. Minor Carboniferous and late Mesozoic sedimentary sequences rest in unconformity towards the southeast (Tschanz, et al., 1969, 1974). The intermediate Geotectonic Province of Sevilla (GPSE) corresponds to a polymetamorphic complex that includes Paleozoic gneisses and schists with Permian millonitized peraluminous granitoids (Mejía, et al., 2008; Cardona, et al., 2010). The northwestern and youngest Geotectonic Province of Santa Marta (GPSM) comprises an inner sub-belt of Cretaceous imbricated metamorphic rocks (greenschists and amphibolites) and an outer sub-belt of Mesozoic amphibolites, greenschists and phyllites separated by the lower to middle Cenozoic 


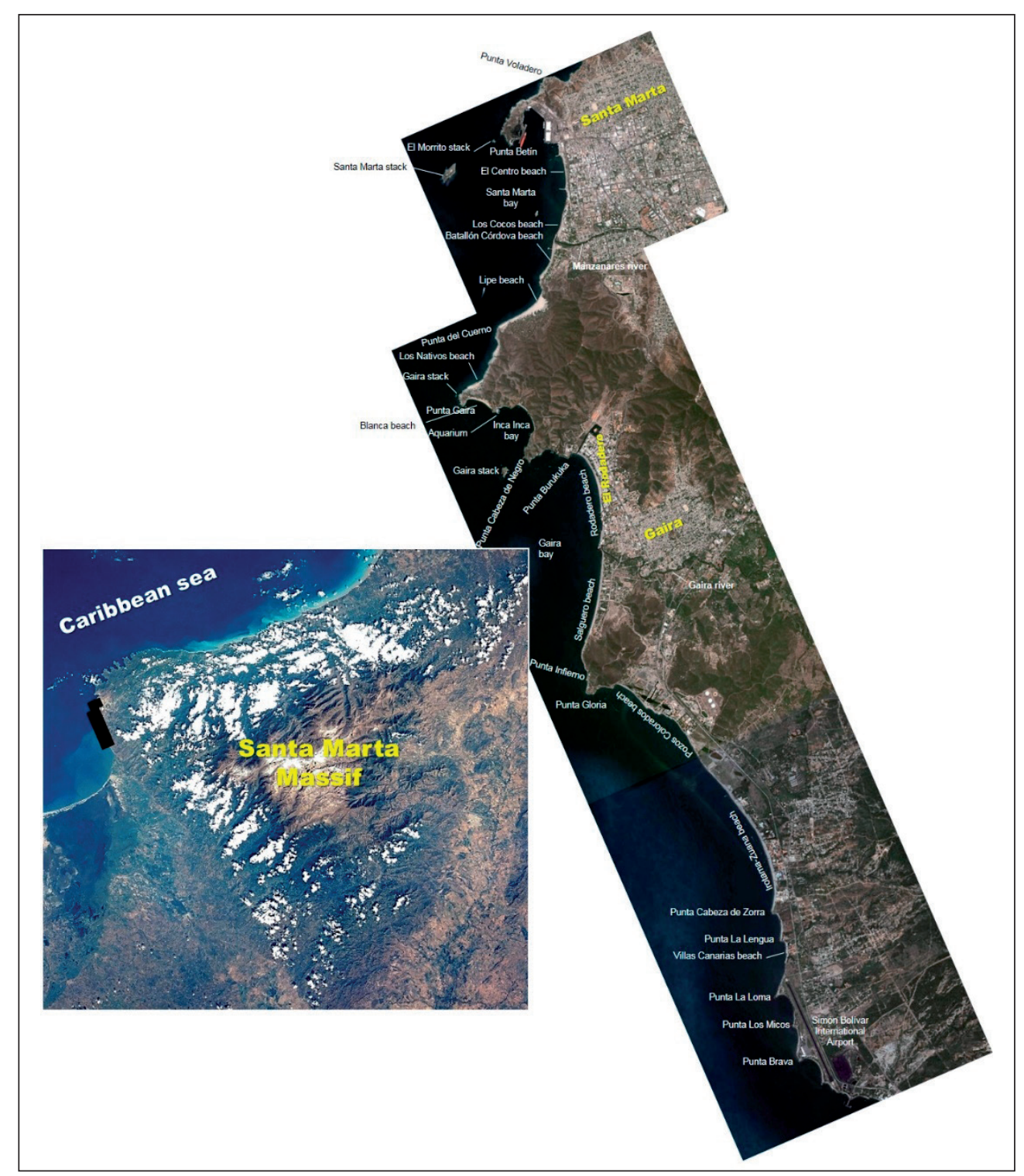

Figure 1. On the left, satellite image of the SNSMM as seen from space by Image Science and Analysis Laboratory, NASA-Johnson Space Center (http://earth.jsc.nasa.gov/sseop/EFS/photoinfo.pl?PHOTO=STS032-71-39) showing the Santa Marta Massif and the study area (black area). On the right, satellite image mosaic showing the study area between Punta Brava and Punta Betín. Image courtesy of Google Earth (http://earth.google.com).

Santa Marta Batholith (Doolan, 1970; MacDonald, et al., 1971). Many tectonic models for the southern Caribbean postulate an accretion of rocks during the late Cretaceous and/or Tertiary from the oceanic island arc of Mesozoic age, but with geological concerns raised by Radelli (1962) and Tschanz, et al. (1969) still to be resolved. Several studies (Duque-Caro, 1980, 1984; Martínez, 1989; Donoso, 1990; Franco, 1990; Suzunaga, 1990; Briceño \& Vernette, 1992; Martínez, 1993; Botero \& Mancera, 1996; Díaz, et al., 1996; Franco \& Gómez, 1996; Velásquez, 2000; Garay, et al., 2002; Serrano, 2004; INVEMAR, 2004; Bernal, et al., 2005; Idárraga, et al., 2011) have referred to the Colombian Caribbean from different points of view such as the state of its marine and coastal environments, its geological, geographical and geomorphological threats, its climatology, hydrography, biology and ecology, its environmental quality, ecosystems, biodiversity, and the management and use of resources. The variety and complexity of the landscape in the continental coastal area between Punta Brava and Punta Betín is the result of the interaction of particular geological conditions, hydrodynamic and atmospheric aspects, biotic and human activities, and occupancy of the coasts, among others. The stability of coastal areas depends on a number of interrelated factors, which have to do with the physical aspects of their configuration and design, and with the dynamic agents acting on them. 


\section{Methods}

This study started with a compilation and analysis of existing geological data, geomorphology, climatology, hydrography, oceanographic processes (waves, currents, tides), geological mappings, aerial photographs, land use, zoning plans, action plans by corporations involved in the area, as well as information from the authorities and beneficiary population within the study area, among others. We carried out a preliminary interpretation of aerial photography to define the most important geological features, the geomorphology and the land use within the study area, and to identify several coastal processes. We interpreted photographs using the following flight lines as established by the Colombian Instituto Geográfico Agustín Codazzi (IGAC): VV WWS M29 AMS 28 JAN 54136 2608-2609 and C-2447 000099-000101. Fieldwork was carried out using a 1:25.000-scale topographic map. In order to obtain geological and geomorphological information, we made several field visits between April and July 2005. We conducted a general survey of the area after sectioning it to study the outcrops. We mapped geological and physical aspects (geomorphology) to identify and characterize the main lithological and geomorphological units in low-lying coastal areas and rocky coastal relief especially in the coastal landforms product of deposition and erosion processes. We also conducted a mineralogical and textural analysis on sediments collected in several beaches with the help of a LEICA GZG binocular lens.

\section{Results}

Geology of the study area. The crystalline basement of the GPSM was observable in the study area containing very important evidence on the geological evolution and the coastal evolution dynamics of this important tectonic zone. Figure 1S, http://www.raccefyn.co/index.php/raccefyn/article/download SuppFile/387/1581, summarizes the geology of the study area and the main lithostratigraphic and structural features.

Lithology. The coast between Punta Brava and Punta Betín consists of lowlands bordering a high relief Paleogene hinterland. Lowlands are riverine plains and deltas, tidal flats, coastal dunes and sand bars, formed during the Quaternary by a combination of processes such as fluvial and coastal erosion-accretion, and by the control of ancestral landform architecture, such as remnant Quaternary ridges and large outcrops of Paleogene bedrock. Metamorphic rocks belonging to the Gaira and Taganga groups, igneous rocks of the Santa Marta Batholith and a series of beach deposits occur in the study area. This section briefly describes the mapped lithological units. Metamorphic rocks are the predominant lithology, represented by locally calcareous chlorite, sericite and graphite phyllites, and micaceous, actinolite and talc schists and minor graphite schists of Paleogene age, which reached the greenschist facies. These rocks outcrop in rocky coastal areas in the hills of Punta Gloria and Punta Betín and San Fernando. There are igneous rocks represented by a plutonic complex within which we recognized different compositional varieties (quartzdiorite, granodiorite to hornblende granodiorite) based on their petrographical characteristics. These varieties grouped into the following units: Santa Marta batholith and Buritacá pluton, hybrid rocks, muscovite granite, Palomino pluton, and hornblende diorites, all of them of Paleogene age. These rocks are characteristic of coastal outgoings and hills. Some smaller igneous bodies occur as sills or dykes that follow or cut, respectively, the metamorphic foliation of andesitic, dacitic and diabasic composition. Sedimentary rocks are absent in the study area although it is possible to recognize Quaternary deposits related to drains depositing sediment in the coastal plains and beaches formed and transported by the sea. Beach deposits, characteristic of the Caribbean Sea, outcrop in Santa Marta, Ciénaga Grande and the mouth of the Magdalena River. Gray, somewhat stratified and semiconsolidated deposits, with fine sandy and clay levels, occur between the mouth of the Palomino River and Santa Marta. In some sectors, silty clay sediments occur, mainly in flood zones, which result from periods of intense rain. The Florín, Palangana and Jordán faults, as well as several satellite faults and alignments involving the city of Santa Marta represent the main tectonic features. In general, metamorphic foliation is $\mathrm{N} 15-50^{\circ} \mathrm{W}$ dipping $20-45^{\circ} \mathrm{SE}$, which may vary in some areas where it is approximately EW dipping $\mathrm{S}$ or N20$40^{\circ} \mathrm{E}$ dipping $15-40^{\circ} \mathrm{SE}$. The internal structures reveal the occurrence of folding and fracturing, with strongly folded areas constituting the most prominent features. Folds are seen further into the hills (e.g., Punta Gloria), and they can be parallel, ptigmatic or inharmonic without presenting a specific distribution. An obvious structural feature is the presence of a large number of hydrothermal veins with thicknesses that range from millimeters to meters. Their morphology and relationship to the regional foliation is equally varied. Based on their structural relationships with the rock sticking, it was possible to identify various topologies, mainly of quartz (and minor calcite) veins recognizable at outcrop scale. General aspects about the geological units cropping out in the study area are shown in Figure 2S, http://www.raccefyn.co/index.php/raccefyn/ article/downloadSuppFile/387/1582, and described in the following section.

Metamorphic rocks. Well-exposed pyrite-bearing chlorite phyllites occur along the coastline from Blanca to Lipe beaches. They show a pale green color and consist mainly of chlorite and quartz, with pyrite porphydoblasts ranging from 0.3 to $1.5 \mathrm{~cm}$ in size. These rocks present quartz veins parallel to foliation $\mathrm{N} 40^{\circ} \mathrm{E} / 80^{\circ} \mathrm{SE}$. Dikes of foliated fine-grained gabbroic rocks cut pyrite-bearing chlorite phyllites. Goethite fully replaces pyrite. Chlorite phyllites crop out from the Punta Cabeza de Negro to Blanca beach and in the Córdova Battalion area. They show a green color and are composed of chlorite and quartz. The appearance of these rocks differs from the pyrite-bearing chlorite phyllites only by the absence of pyrite. They show an almost vertical foliation 
$\mathrm{N} 40^{\circ} \mathrm{E} / 80^{\circ} \mathrm{SE}$. Within this unit there are scattered gabbroic to andesitic dykes cutting the foliation $\mathrm{N} 35^{\circ} \mathrm{W} / 36^{\circ} \mathrm{NE}$. In some sectors (e.g., Blanca beach) black to translucent gypsum crusts, with a thickness of approximately $20 \mathrm{~m}$, occur (Figure 2Sa). Quartz veins occur, sometimes translucent, parallel to the foliation, with thicknesses from 1 to $7 \mathrm{~cm}$. Quartz schists are observed in the northern part of the Gaira bay, and in the northern part of El Rodadero. They also crop out along the road from Santa Marta to El Rodadero (Ziruma) and in some isolated hills. These metamorphic rocks are essentially composed of quartz and mica, although in some cases it is possible to distinguish pyrite porphydoblasts ranging from 0.5 to $1.5 \mathrm{~cm}$ in size. They show a foliation $\mathrm{N} 40^{\circ} \mathrm{E} / 56^{\circ} \mathrm{SE}$, which sometimes develop asymmetrical folds (Figure 2Sb). These rocks are strongly jointed (Figure $2 \mathrm{Sc}$ ). Quartz veins with a lenticular structure occur following the foliation (Figure 2Sd), which decrease in thickness from 3 to $15 \mathrm{~cm}$ toward the top of the unit. A large number of small, foliated andesitic dikes can also be seen, with thicknesses from 10 to $30 \mathrm{~cm}$, which mostly cut to a pre-existing foliation. Along the road from Santa Marta to El Rodadero, mica schists with thin intercalations of graphite and siliceous schists crop out. They show a predominant foliation $\mathrm{N} 45^{\circ} \mathrm{E} / 39^{\circ} \mathrm{SE}$ and a crenulated schistosity (Figure $2 \mathrm{Se}$ ). These rocks contain mainly quartz and muscovite. They show concordant quartz veins locally developing a lenticular structure (Figure 2Sf). Locally, fine-grained amphibolites lenses and pegmatite dikes cut this geological unit. Amphibole schists occur along the road from Santa Marta to Gaira mainly consisting of amphibole schists with a predominant foliation $\mathrm{N} 54^{\circ} \mathrm{E} / 57^{\circ} \mathrm{SE}$. These rocks are composed of quartz, plagioclase, potassium feldspar, biotite, muscovite and amphibole, although locally they also contain a significant percentage of carbonate and opaque minerals. Bag-shape ultramafic bodies occur in this unit (Figure 2Sg), which have undergone retrograde metamorphism, developing talc bodies following the foliation, where tremolite and actinolite occur. On the other hand, it is common to observe stock works of magnesite, derived from talc, pegmatitic and mafic dikes that cut the foliation. Alternating tremolite-actinolitebearing green schists at a centimeter scale occur within the amphibole schist sequence, developing locally a lenticular structure (thickness up to $7 \mathrm{~cm}$ ) (Figure 2Sh). The units described above are part of the metamorphic sequence of the Gaira schists and Taganga phyllites. These rocks are the result of an early Tertiary regional metamorphism. However, radiometric ages indicate that they formed in the Middle Eocene contemporarily with the Santa Marta Batholith (Tschanz, et al., 1969). Metasomatism and abundant dykes of pegmatite, aplite and dacite affected the Gaira schists. The age of metamorphism on this unit is $58.4 \pm 4.3 \mathrm{Ma}$ (Tschanz, et al., 1969). The Taganga phyllites suffered a lesser degree of metamorphism in comparison with the metamorphic conditions affecting the Gaira schists. According to Tschanz, et al. (1969), this unit has no radiometric dating, but its age can be Paleogene-Neogene (?).
Igneous rocks. The Santa Marta Batholith corresponds to a very well exposed granodioritic intrusive body, outcropping along the coastline of the Gaira bay. In the urban area of El Rodadero there are some relics of this geological unit, which prevailed after urbanization, and allow to analyze its texture and structure. Its mineralogy is typical of S-type granites, taking into account that it contains visible garnets at outcrop scale. Figure 2Si illustrates the occurrence of this intrusive body, which shows fine-grained texture and a preferential alignment of mafic minerals, as well as lightcolored pegmatite dikes. In the same outcrop, a mafic dike shows the same igneous body alignment. Farther to the NW coast of the study area, the same igneous body occurs with a different grain size and well-defined characteristics that reveal a granodiorite composition. The age assigned to this batholith is based on hornblende $(50.7 \pm 2.1 \mathrm{Ma})$ and biotite $(48.4 \pm 1.6 \mathrm{Ma})$, while whole rock (quartzdiorite) datings from $49.1 \pm 6.4$ to $50.7 \pm 2.1$ Ma does not exceed $52.8 \mathrm{Ma}$ (Eocene) (Tschanz, et al., 1969).

Sedimentary rocks. Sedimentary rocks are absent in the study area although it is possible to recognize Quaternary deposits related to drains depositing sediment in the coastal plains and beaches. Beach deposits, characteristic of the Caribbean Sea, occur in several sectors, including the Santa Marta and Gaira bays, which are somewhat stratified and semi-consolidated, with levels of fine-grained sand and clay. The age of these deposits has been calculated as Holocene (Tschanz et al., 1969). The occurrence of silty and clay sediments, mainly in areas of flooding, which result from periods of intense rain, is common.

Structural geology. We defined the structural features described below based on the interpretation of aerial photographs because access to the higher elevations was very difficult and dangerous due to the characteristic arid and thorny vegetation that covers the slopes of the mountains, although in some cases, field control enabled the access. The local tectonic features are represented by faults, especially the Florín, Palangana and Jordán faults, as well as several satellite faults and important lineaments involving the city of Santa Marta, which manifest in the presence of fault hooks, fault saddles, and displaced hills. We registered the displacement of a hill near the Cordova Battalion presenting an elongated shape that is different from other hills in its linearity, which is the result of the Tigre fault manifested in the development of fault saddles and the presence of small isolated hills in Santa Marta. We can observe a strong jointing of Punta Gloria in the coastal cliffs, with the development of satellite faults and lineaments such as those mentioned above. In general, the metamorphic foliation is $\mathrm{N} 15-50^{\circ} \mathrm{W}$ dipping $20-45^{\circ} \mathrm{SE}$, which can be approximately EW dipping south or N20-40 ${ }^{\circ} \mathrm{E}$ dipping $15-40^{\circ} \mathrm{SE}$. Strong folding developed mainly in hills (e.g., La Gloria hill). Parallel, ptigmatic or inharmonic folds occur, although without a specific distribution. An obvious structural feature in the area is the presence of a large number 
of hydrothermal veins, which may present thicknesses in the millimeter to meter scale. Their morphology and relationship to the regional foliation is equally varied. Based on their structural relationships with the host rock, various topologies, mainly of quartz veins, are recognizable at outcrop scale: 1) Millimeter to centimeter-scale quartz veins, which are concordant with the metamorphic foliation developing boudinage. These veins are contemporaneous with the foliation, preceding the metamorphic rock deformation. 2) Quartz veins with thicknesses ranging from 0.5 to 2 $\mathrm{cm}$, which are discordant (nearly perpendicular) with the metamorphic foliation. Their formation was subsequent to the veins described above. 3) Quartz veins with thicknesses of 0.5 to $3 \mathrm{~cm}$, which are discordant (with different oblique angles) with the metamorphic foliation. Field relationships indicate that these are the youngest of the three families of quartz veins observed.

Coastal landforms. The coastal landforms correspond to any of the relief features present along the coastal areas as the result of a combination of processes, sediments, and the geology of the coast itself (Davis, 2012). The sea level rise results in a spatial shift of coastal geomorphology, which manifests through the redistribution of coastal landforms, which act to attenuate wave and tidal energy and respond to changing energy conditions at a range of spatial and temporal scales (Pethick \& Crooks, 2000). It is a dominant driving force of change for coastal regions, which is becoming increasingly important (Williams, 2013), taking into account the degree to which it will affect the distribution and abundance of coastal landforms (Crooks, 2004). The geomorphology observed in the study area reveals the occurrence of fragile and unstable zones where several phenomena (waves, currents, tides, sediment download, runoff, landslides movements and changes in the landscape due to human action) operate. The high relief hinterland reaches an altitude of $200 \mathrm{~m}$, whereas the lowlands (coastal plains) truncated in some areas where the rocky littoral extends into the shoreline, and manifests itself in the presence of bays and headlands that emphasize the generation of a variety of landforms that give a great view of the landscape. Headlands and bays occur frequently together on the same stretch of the coastline. They form on discordant coastlines, where bands of rock of alternating resistance run perpendicular to the coast. Bays form where weak, less resistant sandy and clay rocks are eroded, leaving bands of stronger, more resistant, rocks such as schist or granite, which form a headland or peninsula. Wave refraction disperses wave energy through the bay and occurs together with the sheltering effect of the headlands, thus protecting bays from storms. This effect means that the waves reaching the shore in a bay are usually constructive waves, and because of this, many bays feature a beach. A bay may be only meters or hundreds of kilometers across. The geomorphologic map in Figure 2 illustrates the main coastal landforms recognizable between Punta Brava and Punta Betín, which we describe in detail below (Figure 3).
Coastal deposition landforms. Landforms of coastal deposition are the result of the material deposited on the coast by the sea, which occurs in areas where there is a large input of sediments from rivers, beaches or cliffs, long shore drift and an irregular coastline (Nagle, 2000). In addition to beaches, a range of unique coastal deposition landforms exists such as coastal plains, inner lagoons, spikes, beach ridges, low flood zones, flats with sand dunes or cuspate forelands. Additionally, the formation of these landforms depends on the process of long shore drift, which occurs when waves approach a coastline at an angle, due to the dominant wind. Therefore, there is a sideways component to the swash, which helps to move beach material diagonally up the beach (it travels laterally as well as inshore). Backwash under gravity returns water and beach material directly to the sea perpendicularly to the beach profile. The net result is a zigzag motion that can carry material past the end of a headland. Figure 4 illustrates the coastal deposition landforms in the study area.

Beaches. These coastal deposition landforms occur extensively along the coastal area defining a narrow strip except at some places where they are cut by the Manzanares and Gaira rivers and interrupted by rocky shorelines. In the Santa Marta, Inca Inca and Gaira bays, as well as in the hotel sector, important beach areas occur. All along the shore, the beach gently slopes. Most beaches display a number of features of coastal deposition: cusps, semi-circular scalloped embankments in the shingle or shingle/sand junction, ripples formed by wave action or tidal currents, storm beaches, noticeable ridges at the level of the highest spring tides, and small-scale beach ridges known as berms, which are built up by successive levels of tides or storms. A significant amount of the material forming the beaches comes from erosion of detrital material transported to sea by rivers depositing sediments on the shore.

However, the long shore drift, a stream of water flowing parallel to the beach created by the action of waves breaking at an angle to shore, is responsible for the transport of sediments along the coast. Beaches mostly consist of fineto medium-grained sandy sediments, with a good selection, subrounded grains, high sphericity, mostly composed by quartz, chert, small fragments of shells and minor biogenic material. Several fine- to medium-grained sandy beaches occur (Figures 4a-4e), although gravel beaches (e.g., Blanca beach, Figure 4f) can also occur. Dissipated beaches in the Simón Bolívar International Airport (30-40 m wide) and hotel sectors (e.g., Irotama and Zuana hotels) reach up to $60 \mathrm{~m}$ due to human activity. A well-defined and continuous berm is seen in the Salguero and hotel sector beaches where accumulations of trunks, wood and coarse fragments of shells or other materials of anthropogenic origin, brought by the sea at high tide or during storms, can be seen. Where there are cliffs, there are no beaches, mainly due to the presence of fallen blocks. Los Cocos beach tends to increase slightly its size by the sediment contribution brought by 


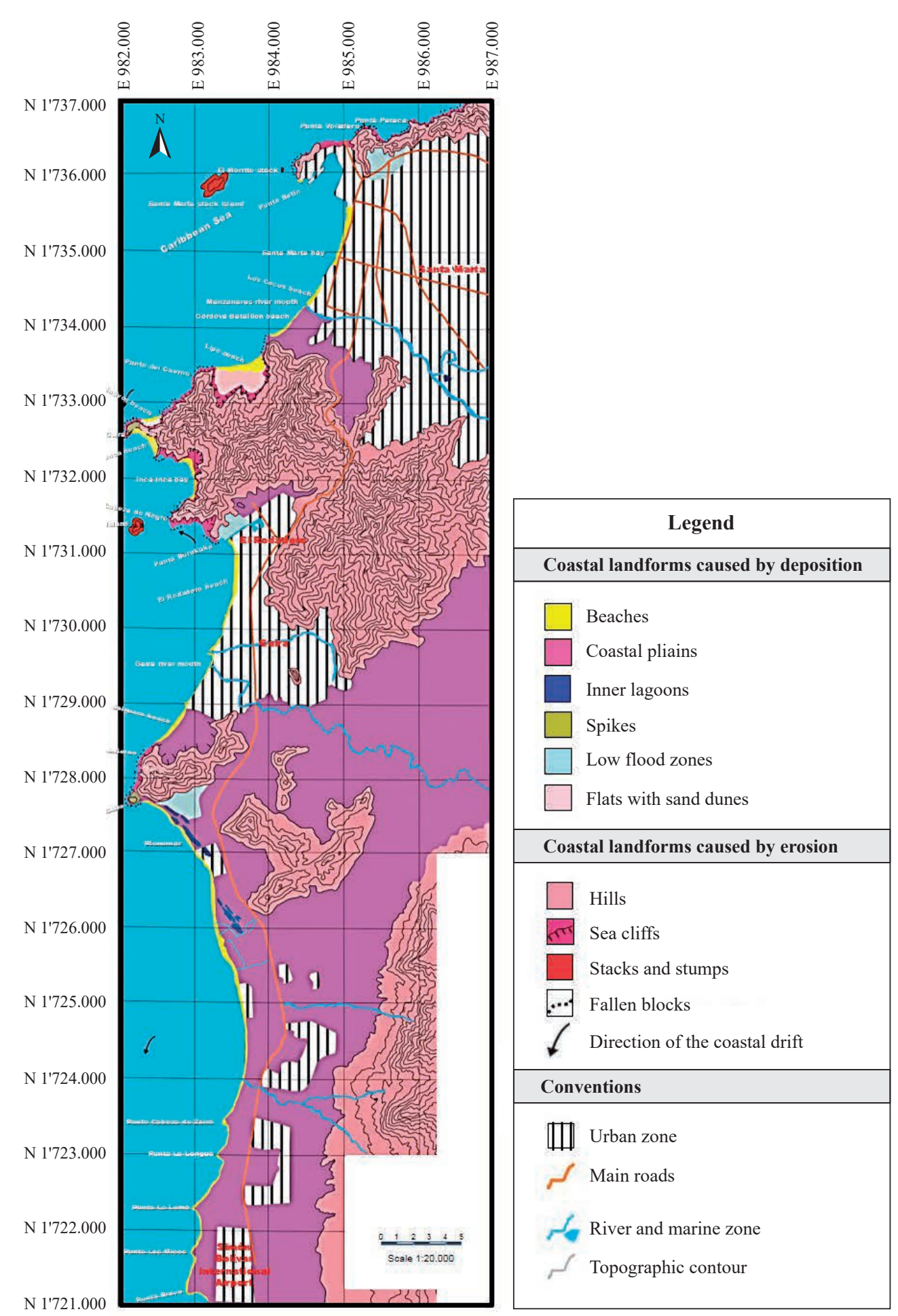

Figure 2. Geomorphological map of the coastline between Punta Brava and Punta Betín. Adapted and modified from Vargas (2006)

the Manzanares River in winter, whereas it significantly decreases marking a surf wave zone in summer. Beaches in Punta Gaira have a steeper slope, coarser sediments and landforms typical of wind action (dunes and rolling). To the north, beaches transitionally show a gentle slope and finer sediments and scarce dunes and rolling.
Coastal plains. These coastal landforms represent extensive lowlands that show some slight topographic undulations. The coastal plains end in the shoreline, and hills or high relief hinterlands breaking into the coastal plains in a different direction generally bound them. In some areas, these are located near current sea level adjacent to the shoreline, and, 

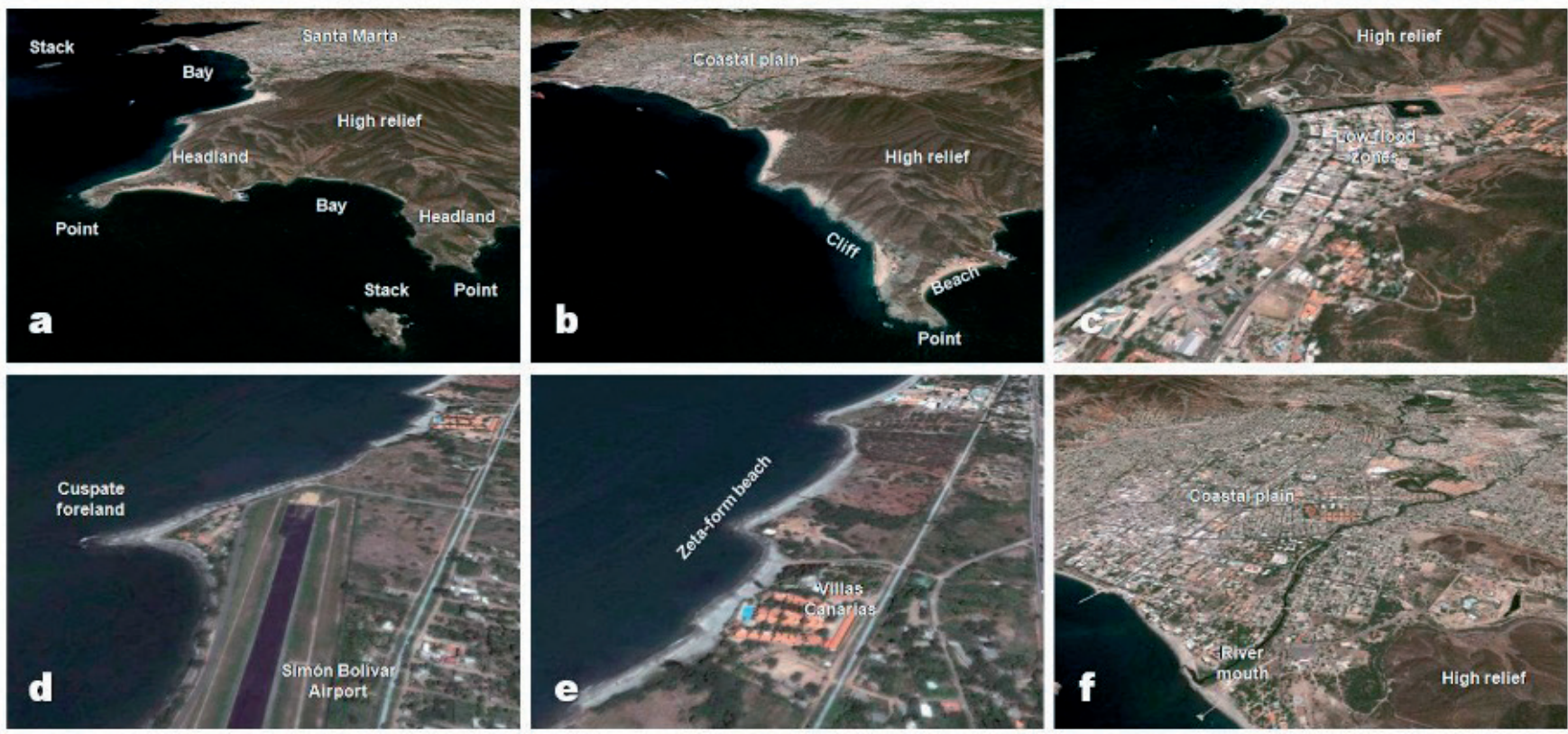

Figure 3. Satellite images showing general aspects of coastal landforms in the study area. Image courtesy of Google Earth (http://earth. google.com)
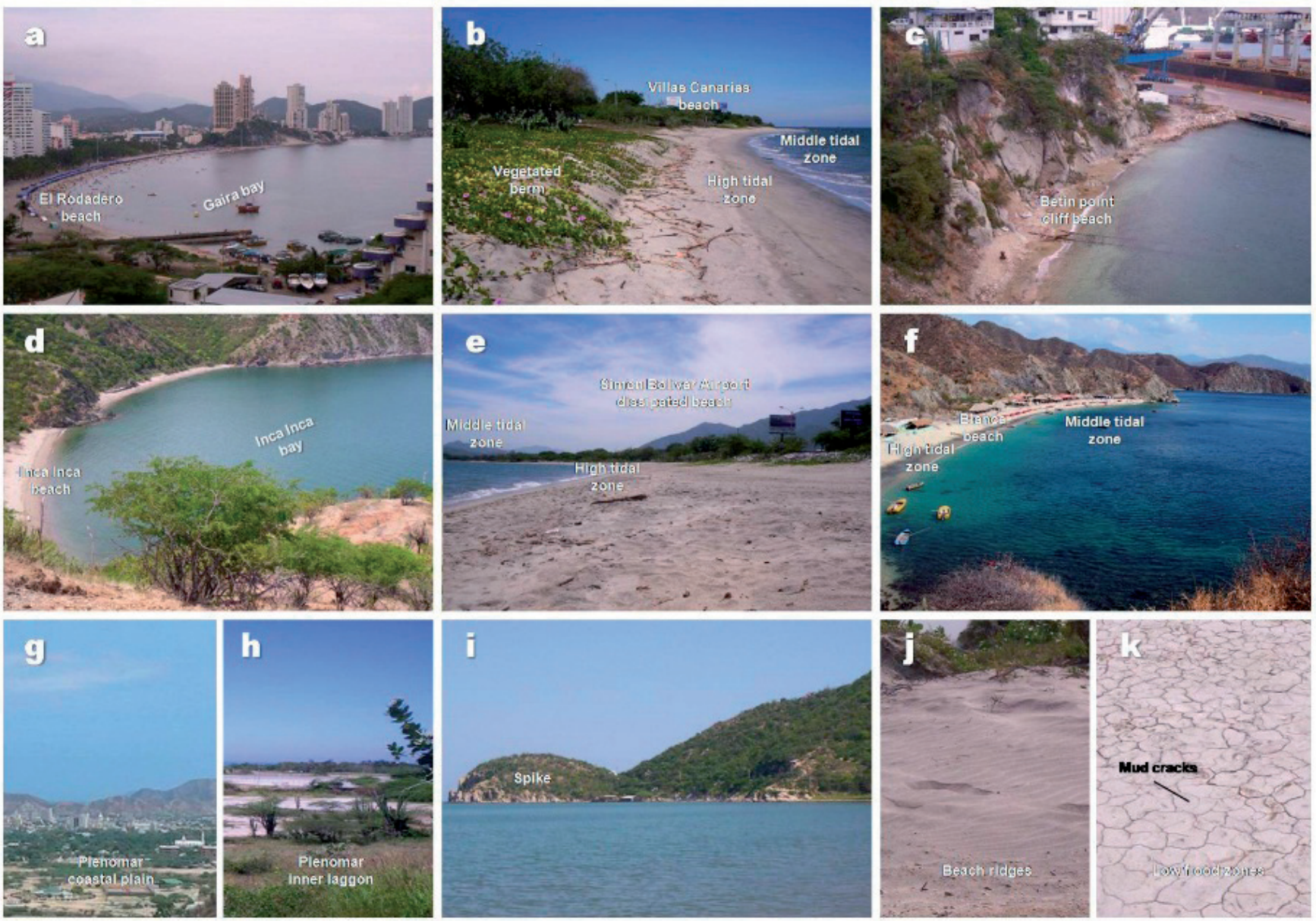

Figure 4. Coastal deposition landforms along the coastal area between Punta Brava and Punta Betín 
in others, the beginning of the coastal plains is located several meters above sea level, and they are associated with marine fluvial processes. Coastal plains can diminish significantly due to land use (e.g., construction of hotels in El Rodadero and Santa Marta). At the Simón Bolívar International Airport area, both the coastal plain and vegetation cover develop due to the limited land use. The largest coastal plain occurs near the hotel sector. Santa Marta developed on a coastal plain, which was progressively lost due to the development and spacing of this touristic city. Manzanares River floods also influenced it. Another coastal plain occurs in the Plenomar sector where it occupies a small area bounded on the continent by hills or high relief hinterlands (Figure $4 \mathrm{~g}$ ), and whose origin is related to the floodplain lakes caused by the growing season or storm surges.

Inner lagoons. The inner lagoons have different extensions and lie adjacent to the shoreline. However, some of them are separated from the sea by narrow sand bars, thereby creating a relative influence of the sea on the lagoon. In contrast, there are lagoons that despite their situation on spikes, are distant from the present shoreline and do not receive the direct influence of the sea. The interior lagoons are present near low flood zones, and some of them resulted from past floods or human action. Examples of this type of landforms occur in La Escollera lagoon and the Plenomar sector (Figure $4 \mathrm{~h}$ ).

Spikes. The most common coastal landforms are spikes. The longitudinal extent and strength of these may vary according to the contribution of material and other oceanographic and geological factors. Spikes mark the direction of the littoral drift, which is generally SW for the Colombian Caribbean, explaining the overall trend of the headlands toward this direction. Most of these landforms have a hook showing the greatest erosive effects due to marine dynamics, since the waves struck with greater force on them. Besides this erosive effect, geological features (high jointing) of the area also accentuate the spike shape and generate the development of stacks as in Punta Gloria (Figure 4i).

Beach ridges. Beach ridges are moderately undulating features of marine depositional type formed parallel to the coastline. Well-developed beach ridges occur in Punta Brava. Each ridge shows gentle longitudinal depressions that run parallel to the ridge. They may appear as a single groove or a series of parallel grooves. In general, these coastal landforms are less than $20 \mathrm{~cm}$ high, and some times it is difficult to recognize them. This type of landforms occur in Punta Brava, located towards the side of the high tidel zone, on a mound of approximately $1 \mathrm{~m}$ high, revealing how they are influenced by wind action (Figure 4j). These ridges occur along the beaches at high tidal zones and are important to understand how the wind acts as a changing factor and establishes accretion zones.

Low flood zones. They are flat and low coastal areas whose extension is variable. They are associated with sand spikes. In winter these areas capture rainwater, thus acting as temporary shallow lagoons, while in summer they have clay soils that generally show mud cracks (Figure 4k). These low flood zones located very near the shoreline are frequently flooded due to high tides or, sometimes, storm surges. These landforms occur to the NW of La Escollera lagoon, between La Gloria hill and the Plenomar sector, along with an ancient flood plain in Pescaíto, which is outside of the study area. Near La Escollera lagoon, desiccation cracks are not well marked, but temporary shallow lagoons with clay soil development are characteristic in the rainy season. In the Plenomar sector, temporary shallow lagoons and desiccation cracks were observed.

Flats with sand dunes. These landforms correspond to sandy low-lying coastal areas, which are associated with the formation of spikes. They extend from the present beach to the edge formed by ancient cliffs, and are extensive areas of unconsolidated material associated with ancient beaches, which now may or may not be vegetated. Often thin sand covers occur on these flats. In other areas, they present scattered sand mounds of low elevation (less than $1 \mathrm{~m}$ ) and no preferred orientation, which relate to the dynamic action of wind. Flats with sand dunes generally occur in all sand spikes in the study area. These landforms were observed in the beach around Punta Gaira, where they manifest as coarse- to very coarse-grained sandy plains whose width varies from 10 to $15 \mathrm{~m}$. They are about $30 \mathrm{~m}$ away from the present beach. Due to their morphology and location, they are subject to periodic flooding.

Cuspate forelands. Cusp-shaped geoforms are common along several beaches. They grade in size from small beach cusps to large cuspate forelands. Large seaward projecting accumulations of loose marine sand or gravel form a cuspate foreland, such as that observed in the Simón Bolívar International Airport area (Figure 3d). Ideal sites for the formation of these coastal landforms include those locations where a major change in coastline direction occurs. Many cuspate forelands have been built by the progradation of a series of beach and dune ridges as sediments deposited in the slack water zone between two coastal eddies.

Coastal erosion landforms. The landforms of coastal erosion are the result of large waves crashing onto a shore with a tremendous amount of energy and a significant eroding effect; several unique erosion features commonly form on rocky shores with strong waves (Earle, 2015). The most spectacular scenery found along coastlines is the result of the effects of wave erosion (Magbagbeola, 2011). Landforms of coastal erosion include cliffs, wavecut platforms, caves, arches, stacks, stumps, and headlands, amongst others. Figure 5 illustrates the landforms of coastal erosion in the study area.

Headlands. As mentioned above, headlands represent outstanding landforms occurring between two bays and they consist of resistant igneous and metamorphic rocks, which are more resistant to abrasion. Refraction of waves occurs on headlands concentrating wave energy on them, 

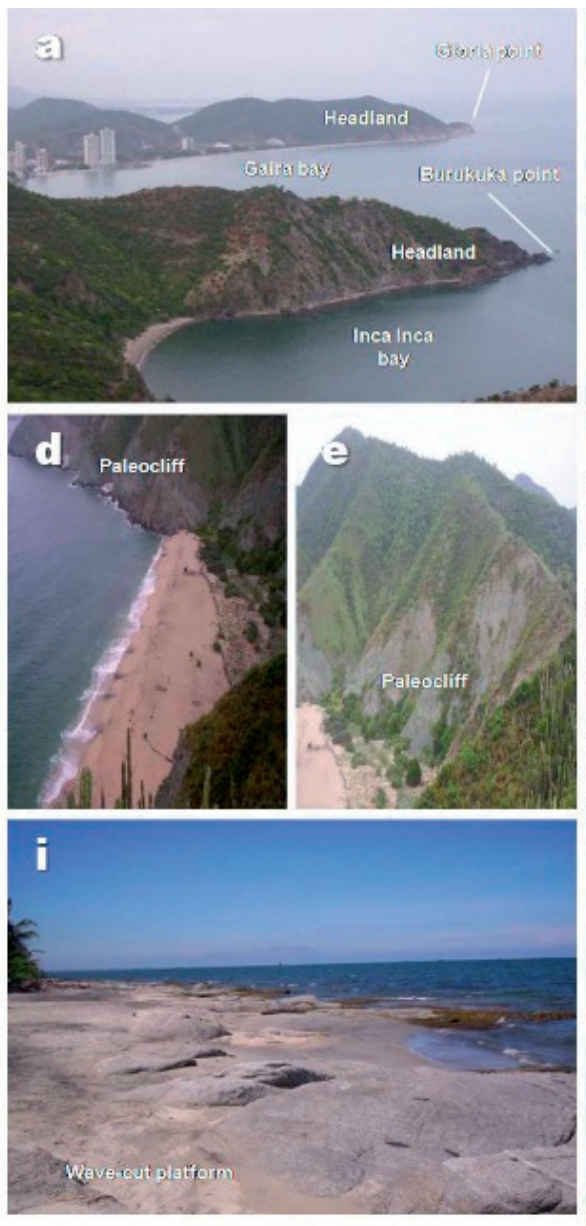
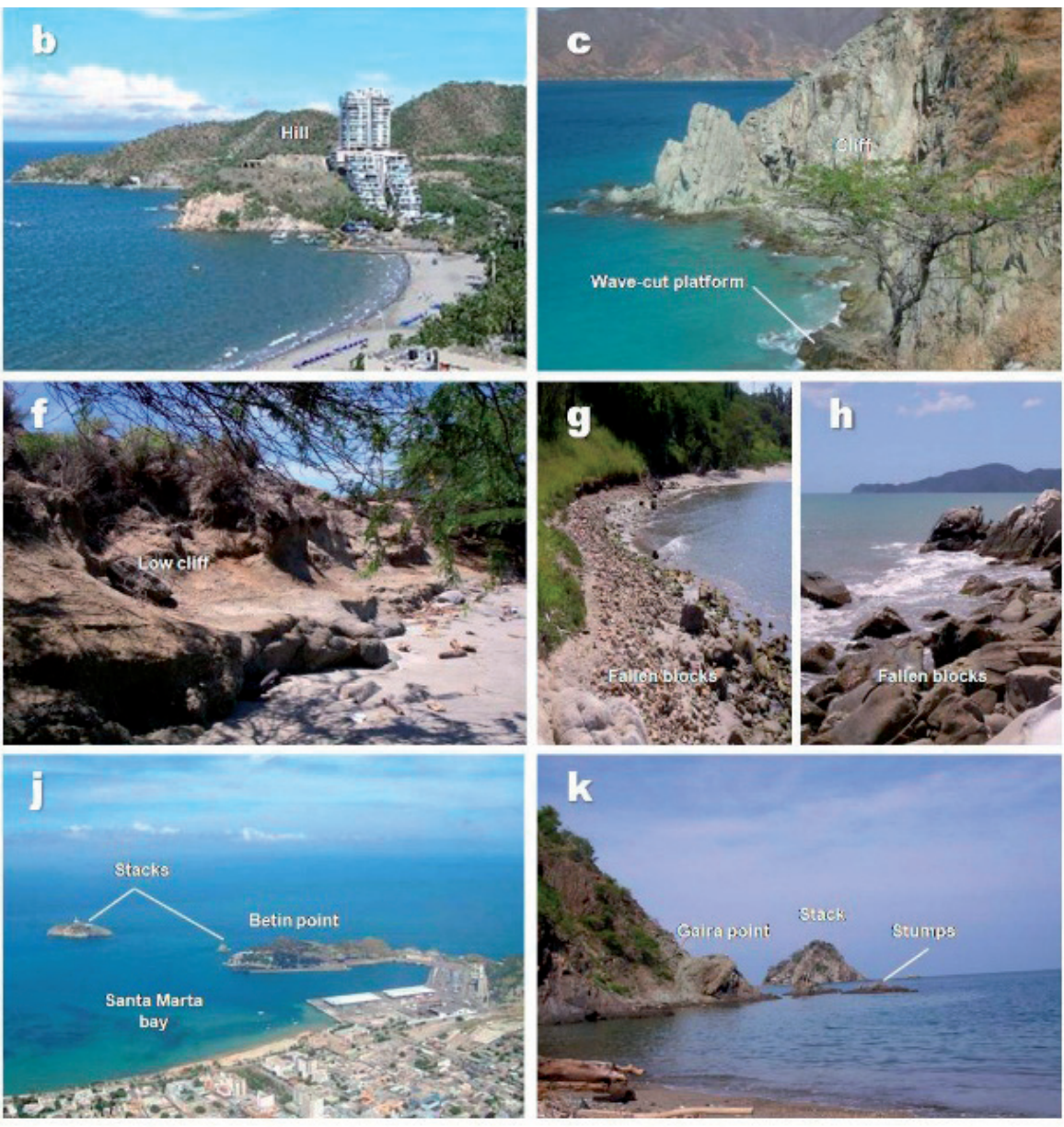

Figure 5. Landforms of coastal erosion along the coastal area between Punta Brava and Punta Betín

so many other landforms, such as caves, arches and stacks, can develop. These landforms present strong jointing and surrounding cliffs ranging in size. They are very important due to their substantial influence on the erosion-accretion effect as they modify the wave direction and, in a way, also that of the littoral drift, being decisive in the sedimentology of the study area. Headlands form when the sea attacks a section of coast with alternating bands of hard and soft rock. They determine the coastal settings as immersion or transgression type coasts that represent abandoned coastlines or berms revealing the coastline regression. A sea level rise or subsidence of land leading to the immersion of a high relief hinterland (hill) with the presence of drains causes a steep coast with bays, such as Santa Marta, Inca Inca and Gaira, separated by headlands (Punta Brava, Punta Gloria, Punta Burukuka, Punta Cabeza de Negro, Punta Gaira and Punta Betín). Examples of headlands are shown in Figure 5a.

Hills. They are topographic promontories adjacent to the coast, which stand along a wide coastal plain (Figure $5 b)$. Generally, the hills have a relief with gentle slopes and heights of about 100-200 m, comprising a variety of sedimentary material. In some sectors, landslides and erosion due to overgrazing and gullies can be observed. The undulating morphology results from the action of endogenous (faulting or folding) and exogenous (climate and erosion) processes. The first occur at La Gloria hill and in the coastal cliffs of Punta Gloria, marking a trend of satellite faults. Exogenous processes, although lesser, also operate, and they have modified hills in the Inca Inca bay. In Inca Inca bay and Punta Gloria (Pozos Colorados and Plenomar), hills show their influence. In the first of them, hills present topographic heights between 100 and $200 \mathrm{~m}$ and a moderate to high drainage density, while in the latter, they do not exceed $100 \mathrm{~m}$ and the density of drainage is low. These hills are part of the SNSM foothills, which reach the littoral, significantly influencing the development of coastal landforms such as headlands, making them more resistant to erosion, and forming a series of cliffs in between which bays have formed. The following hills stand out from north to south: Punta Betín, Punta Gaira, Punta Burukuka and Punta Gloria, along with other mounds near the Santa Marta - Barranquilla road, particularly in El Rodadero, Ziruma and Pozos Colorados.

Sea cliffs. These landforms represent escarpments that mark abrupt changes in slope, formed by marine erosion (Figure 
5c). They generally consist of a rocky substrate and their height is variable (high and low cliffs). In high cliffs, the coastline has a narrow beach close accompanied by a slope of generally inclined walls. In addition, they limit terraces or shells with heights equal to or greater than $10 \mathrm{~m}$. Along the coast, high cliffs represent the common type, showing convex to vertical profiles with heights of 10-30 m. Examples of them occur in Punta Betín, Punta Gaira, Punta Burukuka and Punta Gloria. The escarpments caused by the action of the sea are not longer than its direct action and they are separated from the present coastline, developing paleo-cliffs (Figures $5 \mathrm{~d}$ and 5e), which are well exposed in Los Nativos and Lipe beaches in the NE side of Punta Gaira. This not only reveals the retreat of the sea but also the development of a process of accretion. In the study area, cliffs are not related to fluvialmarine terraces as usually occurs on the Caribbean coast. On the contrary, there are cliffs associated with hills and mountains belonging to the SNSM foothills. Wave action generates typical erosional landforms that depend on rock compaction and structure forming these foothills, mainly composed by schists and phyllites, with wave and erosion action through the foliations and joints of these metamorphic rocks. The erosion on the cliff is shallow and results from rock falls, possible landslides, water action (cracks, caves and alveolar or honeycomb shapes) and bioerosion, the latter favored by the presence of organisms such as mollusks and plants that adhere to bedrock. On the other hand, in low cliffs (Figure 5f), the height of the coastline does not exceed $10 \mathrm{~m}$. Generally, the bedrock is undermined and it is common to find separate rock slabs at the base of the cliff. These cliffs are mainly marked where marine erosion has been acting more strongly on the beaches, as is the case in the Simón Bolívar International Airport area, whose cliffs rarely exceed $5 \mathrm{~m}$ and have a very narrow beach. At the foot of the active cliffs accumulations of blocks, whose size can reach a $2 \mathrm{~m}$ diameter in average, occur often formed by the material from the cliff itself (Figures $5 \mathrm{~g}$ and $5 \mathrm{~h}$ ). The accumulation of these blocks reflects the instability experienced by the bedrocks by the action of waves. The existence of many of these features depends upon the maintenance of a vertical cliff-face through an on-going cycle of undercutting, collapse and retreat. When waves break at the foot of a rock face, marine erosion processes cretated a wave-cut notch. Over time, a section of rock removed from the bottom of the cliff face, leading ultimately to the collapse of the unsupported section above, developed a wave-cut platform (Figure 5i).

Stacks and stumps. During erosion process caused by sea action over a cliff, waves can attack its base forming a cavern. When two caverns in the opposite sides join, they form coastal arches, which finally collapse due to the gradual fall of their roof, developing isolated remnants of rock as small rocky stacks. They typically represent more resistant portions of the ancient cliff that survived for a time to form stumps before the sea destroyed them. The Santa Marta and
El Morrito stacks represent extensions of Punta Betín (Figure $5 \mathrm{j})$. The first of them is located somewhat away from the coast, $1 \mathrm{~km} \mathrm{SW}$ of Punta Betín, whereas the latter is located $30 \mathrm{~m}$ from the coast. The Gaira stack (Figures $5 \mathrm{e}$ and $5 \mathrm{f}$ ) is located about $300 \mathrm{~m}$ from Punta Burukuka, on the western part of the Gaira bay. Its size reaches up to $30 \mathrm{~m}$ high. Some stacks that fail to stand out above the sea level represent a threat to ships moving near the coastline. These features may be marked in headlands that have no stacks today, as can be seen in Punta Gloria and Punta Gaira. Towards Punta Gloria, a coastal stack no more than $5 \mathrm{~m}$ occurs (Figure 5k). Stunning coastal promontories or stumps represent coastal landforms, which form when a stack erodes, leaving a rocky stack usually small enough to be submerged at high tide as shown in Figure 5k.

The erosion and accretion processes. Shoreline changes occur because of erosion and accretion processes. The erosion is a condition of the coast on the skids because of the activities of seawater, whereas the accretion represents the material addition caused by the deposition of material from a river (Prasita, 2015). The shoreline represents the area where the ocean and continent interact and where geomorphological processes develop quite fast compared to other oceanic and continental areas. Waves, sea currents, tides and other ocean phenomena erode the solid material of the coast, promoting its transport and deposit in other areas, and continually modifying the coast morphology as revealed by the occurrence of different landforms as described above. Rivers, meanwhile, transport continental sediments and accumulate them on the shoreline forming deltas. Erosion and sedimentation coasts can form due to these phenomena. The coastal erosion landforms present steep rocks or cliffs and caves (for the sector of headlands). Generally, the active process of erosion caused by waves, tides and sea currents crumbles the base of cliffs and ultimately leads to their collapse and retraction of the coast. In this way, the so-called abrasion shelves formed. The sedimentation coasts show sandy beaches (e.g., Lipe, Blanca, and El Rodadero beaches). The Manzanares and Gaira rivers supply and transport sediments in a process that can form new beaches. The city of Santa Marta is traversed by these rivers, which originate in the SNSM massif. The Gaira River, which covers more territory within the city than the Manzanares, is one of the most polluted rivers in the department of Magdalena. The Gaira inlet extends from Punta Gloria on the south to Punta Gaira on the north, and its coastline is about $10.94 \mathrm{~km}$ long. The beaches in this area have similar characteristics and present gravel sandy marine and clayed sandy fluvial sediments. In some sectors, particularly at Punta Gloria and the mouth of the Gaira River, carbonate sediments and fragments of igneous and metamorphic rocks occur. The origin of these sediments, as well as those from seabed, relates to weathering and erosion of the crystalline basement rocks that make up the coastal relief of the Santa Marta region, and the influence of climate, 
but also the fluvial contribution of the Magdalena River basin and the estuary of the Ciénaga Grande de Santa Marta. However, a third factor that has influenced both the instability of the seabed and the current sedimentary characteristics of the beaches is the dredging for the recovery of El Rodadero beach, which has been necessary, as the coastline had suffered a setback that could cause the entry of sea water into the urban area. The only direct discharge of fresh waters occurs on the south of the Gaira inlet and comes from the Gaira River, polluted by domestic and industrial waste discharges continually dumped in it. The Manzanares River crosses the city from northeast to southwest; its channel receives the discharge of sewage and liquid wastes, and besides, houses are extremely close to the river. In the littoral, interaction processes among the lithosphere, hydrosphere, biosphere and atmosphere are quite marked and rapid. All these factors evidence how coastal areas play an important role in biogeochemical cycles and, in general, in the ecosystem. Generally, the beaches of the Colombian Caribbean region are subject to seasonal weather changes. The study area presents a predominance of trade winds of N-NE direction. Erosive phenomena have affected beaches causing considerable decreases of the beachfront. On the other hand, in the rainy season, when low intensity and variable direction winds occur, beaches are reconstructed to increase their amplitude. These two situations explain why the coastal boundary configuration and SW coastal drift (in its direct relation to wave action) influence of hydrodynamics on this sector of the littoral. The interaction of these factors is evident in the loss and gain of land responsible for the extensive coastal spikes as can be observed in Punta Betín, Punta Gaira, Punta Burukuka and Punta Gloria. Coasts can change quickly due to processes of erosion and sedimentation, and result in new and varied coastal landforms. The main agents contributing to changes in littoral modeling are waves, tidal currents, littoral drift currents (coastal currents), fluvial currents, winds, organisms (corals) and human activity. The main erosion forces among these agents acting on the coastal environment proceed directly from marine activity, waves being the most important agent in the coastal denudation, even if some denudation action can be also attributed to tidal and littoral currents. With regard to supply or loss of sediments, littoral drift currents somehow influence in the region, creating a SW-striking current that allows the transport of sediments in this direction and generates a significant change in the characteristics of landforms. In relation to fluvial currents, they act mainly in the rainy season when the Manzanares River caudal increases, carrying large amounts of sediment, which influence the direction of the drift for Los Cocos beach. In general, the accretion landforms on the coast are relictic, due to the lack of input by present rivers. Erosion is primarily caused by the lack of direct accumulation (the river load does not reach the coastline) and by induced erosion (since littoral drift is not saturated from river input, erosive processes operate on the coastal outcrops). Erosion in the coastal area is evident in the current inability of the Gaira and Manzanares rivers to transport gravel-sized sediment to the coast, at least in large volumes. A decrease in sediment supply from the upstream drainage basins has created an unstable mass balance, because the quantity of solid discharge is less than that moved by the littoral drift (Aiello, et al., 2013). Therefore, we could say that some of the existing sediments originated in periods when climatic conditions were different from today, and these rivers had a higher carrying capacity and greater erosive power. The stability and the movement of the coastline represent its behavioral parameters. Vargas (2006) has discussed these aspects in detail. Based on the stability of the coastline in relation to the dynamic action of the sea, the coast can be consolidated or unconsolidated. A consolidated coast is a coastline formed by rocky cliffs. Examples of this type of coast are present in Punta Gaira, Punta Burukuka and Punta Gloria, where erosive effect of waves has caused cliffs. It can show cohesive and non-cohesive rocky cliffs, depending on the type of material present in them. The cohesive rocky cliffs consist of hard material resistant to erosion, which manifests in sectors where there are granodioritic rocks outcrop showing some resistance to erosion and detachment by gravity. An example of this subtype of cliffs occurs in Punta Gloria, with heights up to $30 \mathrm{~m}$ (Figure 6a). Non-cohesive rocky cliffs reveal the action of waves when they hit the basement of the cliff. In general, rocks of this subtype of cliffs are compact and in some cases show strong jointing, allowing the sea to act with relative ease on them. Figure $6 \mathrm{~b}$ shows an example observed in Punta Gloria. The unconsolidated coast is a low coast, usually formed by beaches easily modified by waves, producing advances and retreats of the coastline in a relatively short time in most cases. An example of this type of coast occurs in Salguero beach (Figure 6c). The directional trend affects the movement of the shoreline, as it exposes the coastline to dynamic processes exerted by the sea. Three types of movements may reflect the behavior of the coastline: erosion, rapid erosion and accretion. Erosion is the process through which material from beaches or cliffs is broken up or removed by the action of the sea. This phenomenon occurs in sectors (e.g., Simón Bolívar International Airport area) where strong abrasion affected cliffs (Figure 6d). In Punta Gloria, jointing and undermining factors affected rocks (Figures 6e and 6f). The rapid erosion process is similar to that previously described, but faster, which can be evaluated using historical records, topographic maps, aerial photographs and/or direct field visits given that erosion is a very dynamic process that must be studied over time. An example of this process occurs in Los Cocos beach, where very rapid erosion has located the beach in the surf wave zone (Figures $6 \mathrm{~g}$ and $6 \mathrm{~h}$ ). Accretion is the opposite process of erosion, as it is a gradual addition of coastal land through the deposition of material transported by waves and currents. There are shoreline features above the present sea level on 

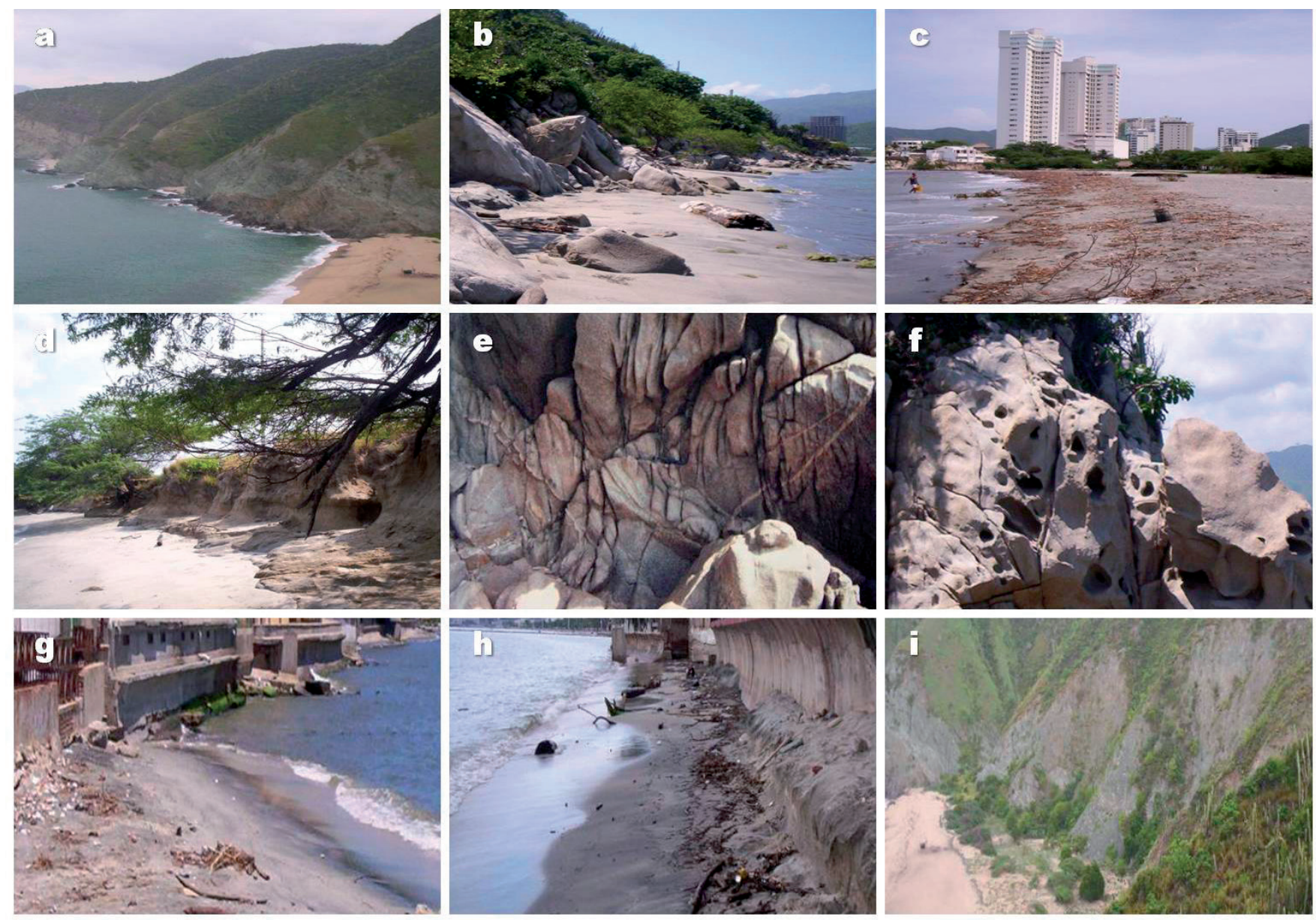

Figure 6. Erosion and accretion processes along the coastal area between Punta Brava and Punta Betín

Lipe and Los Nativos beaches due to the presence of paleocliffs (Figure 6i). No evidence of shoreline below the present sea level was observed, but its existence is not excluded. The coastline of the Santa Marta bay is stable though with local erosion problems. In the Córdova Battalion beach, erosion may be associated with a small canal to the sea and saddles in the rocks. There are shoreline features above the present sea level in Lipe beach. As modifying agent, erosion is a process that affects a large percentage of coasts in the world and it may have catastrophic effects on the environment or affect the safety of their inhabitants, as well as their economic activities.

Although erosion is a natural phenomenon, human activities such as intensive quarrying of sand for buildings and marine protection barriers also influence its acceleration. Coasts are critical because they protect people and property from sea forces, and they are an important ecosystem for fauna and flora, as well as a source for economic activities involving many people, like tourism. Coastal erosion and degradation represent one of the most serious environmental problems affecting the Colombian littoral, which is one of the economic sectors with the greatest impact on our gross domestic product. In recent years, the social and eco-nomic impact of coastal erosion has increased significantly, and it represents a serious risk for large segments of the Colombian Caribbean coast. Several facts indicate that this erosive trend will continue, with large amounts of sediment being transported by littoral drift, the increase of wave energy by the effect of winds during the summer season, and the possible rising of the sea level that can affect portions of the coast. According to Romine, et al., (2016), the asymmetrical distribution of erosion and accretion trends along beaches suggests predominant transport of sediment, with sediment eroded at greater rates from the south side of headlands and deposited towards the bays. Figure 3S, http://www.raccefyn. co/index.php/raccefyn/article/downloadSuppFile/387/1753, shows the suggested erosion and accretion trends and allows to inferr net sediment transport for the study area. We concluded that the most serious and ongoing danger occurs in lower beaches, where an even minimal risings in sea level increase the advance of the sea towards the continent. With regard to changes in the magnitude of erosion on a beach, their rigor is not the same throughout the year, but varies with the climate regime (Martínez, 1993). 
Shoreline changes since 1954. Coastal areas are subject to a wide variety of phenomena, such as sea level variations, storm surges and wave energy, tidal inundations, tectonics and land subsidence, sediment budget changes and anthropogenic activities that continually modify and play fundamental roles in coastal development and exposure to risk of coastal erosion (Aiello, et al., 2013). The shoreline is a useful indicator of mid-term coastal evolution, and instantaneous sea level, length of the run-up, and beach profile changes affect it (Almonacid-Caballer, et al., 2016). Analysis of historical shoreline changes indicated an overall trend of erosion (shoreline recession) along headland sections of beach and an overall trend of stable to accreting beaches along adjoining embayed sections (Romine, et al., 2016). Previous studies (Ramírez, 1959; Raasveldt \& Tomic, 1958; Correa, 1990; Molina, et al., 1992; Velásquez \& Rave, 1996; Delgado, 2002; OrdóñezCardona, 2002; Restrepo \& Kjerfve, 2000; Restrepo, 2001; Ordóñez, 2002; Morton \& Correa, 2004; Correa \& Vernette, 2004; Bernal, et al., 2005; Correa, et al., 2005, 2007; Posada \& Henao, 2008; Rangel-Buitrago \& Posada-Posada, 2005; Rangel-Buitrago, 2009a, 2009b; Rangel-Buitrago \& Anfuso, 2013) have revealed drastic shoreline changes on the Caribbean coast during the past 50 years due to the sea level rise associated to the global climate change, strong surge, sediment input, geological phenomena and anthropogenic activities. According to Church \& White (2011), the global sea level rise is about $1.6 \mathrm{~mm} / \mathrm{yr}$. At time scales ranging from decades to centuries, sea level primarily varies because of anthropogenic climate change and its impacts on ice melt and the warming of the oceans (Church, et al., 2011). The coastal area between Punta Brava and Punta Betín has been affected by important changes since 1954 (Figure 3S), especially the retrogession of the shoreline due to erosion, which has been constant during the last 50 years. A muti-temporal study of aerial photographs revealed the main variations of the shoreline resulting from low frequency (temporal) and long-term processes. We conducted erosion and accretion data analyses after dividing the shoreline in three sectors: Punta Betín - Punta Gaira sector, Punta Gaira - Punta Gloria sector and Punta Gloria - Punta Los Micos sector, and taking into account the main geographic headlands to determine the erosion rates.

Punta Betín - Punta Gaira sector. The Punta Betín - Punta Gaira sector has an approximate length of $8.5 \mathrm{~km}$ (Figure 4S, http://www.raccefyn.co/index.php/raccefyn/article/download SuppFile/387/1754). A maximum retrogression of the coastline of $135 \mathrm{~m}$ has occurred in the port zone. The erosion rates range from 1.96 to $2.35 \mathrm{~m} / \mathrm{yr}$. The strong erosion in this sector is revelaed by the occurrence of El Morrito and Santa Marta stacks, which are located at 60 and $300 \mathrm{~m}$, from Punta Betín, respectively. The loss of land has increased particularly in El Centro beach as the result of inadequate construction of marine structures, such as breakwaters and spurs, which prevent the transport of sediments, and the uncontrolled extraction of construction aggregates (sands) towards the Manzanares River mouth. On the other hand, alternating erosion and accretion processes have occurred in this sector, where accretion has been apparently constant during the last 50 years in Lipe and Los Nativos beaches, mainly along the coastline as evidenced by the occurrence of paleocliffs. Here the coastline advanced during the last 50 years developing beaches $60-90 \mathrm{~m}$ in amplitude. Notable changes due to erosion affected Punta Gaira, which strongly influenced the hydrodynamical conditions. The main cause of its fragmentation was the strong faulting and shearing that occurred in this sector, as well as the strong surge.

Punta Gaira - Punta Gloria sector. The Punta Gaira Punta Gloria sector has an approximate length of $7.5 \mathrm{~km}$ (Figure 4S). The retrogression of the coastline ranges from 88 to $107 \mathrm{~m}$ in El Rodadero, where the erosion rates do not exceed $1.98 \mathrm{~m} / \mathrm{yr}$. In this sector severe erosion has occurred. Along the coastline, stacks are observed at a distance up to $200 \mathrm{~m}$ seaward (e.g., Gaira stack) and $50 \mathrm{~m}$ with minor pillars in Punta Gloria, which serve as markers of ancient terraces and, therefore, of the coastline. Sandy sediments carried by different streams to the coast have helped to keep the beach stability in El Rodadero and Salguero beaches, where the Gaira River disembogues. These sediments maintain a balance with respect to the input and output of materials.

Punta Gloria - Punta Los Micos sector. The Punta Gloria - Punta Los Micos sector has an approximate length of $5.5 \mathrm{~km}$ (Figure 4S). The retrogression of the coastline has reached up to $143 \mathrm{~m}$, although in Punta Gloria a considerable reduction of a spike has occurred. The erosion rate is approximately $2.5 \mathrm{~m} / \mathrm{yr}$. The erosion is intense here, considering that it also acts on a fluvio-marine terrace, where rocks from the cliffs offer no resistance to the onslaught of strong waves. Runoff has played an important role in the disintegration of the terrace, thus facilitating the weakening of materials for subsequent removal. In the northern part, the retreat of the coastline is associated with the fall of rock blocks belonging to the Santa Marta Batholith, a product of the relentless onslaught of the waves on the rock. Towards the hotel sector, a number of relatively wide beaches occurs; however, the change in the coastline is evident by the presence of spurs that affect this sector and, in turn, the erosive trend is evident in the different rock ledges. The homogeneity of land has favored the relatively low rates of erosion in this sector, mainly from the hotel sector to Villas Canarias. The lower slopes contribute to a minimum performance of erosion caused by surge. Moreover, in this sector a considerable human intervention has occurred.

\section{Discussion}

The degree of vulnerability experienced by coastal populations will depend on both the scope of future sea level changes and the capacity of society to adopt adaptive measures to accommodate those changes (Crooks, 2004). The study area is a mosaic of geomorphic complexity, which has been 
analyzed from phenomenological geomorphological, lithogeomorphological, structural and climate perspectives that are intertwined, although in many situations one is more important. Landforms are not the expression of various lithological types but the combination of different agents acting on the same lithology. The phenomenological geomorphology refers to the erosive action, the different types of erosion, the influence of seawater and its role in the evolution of the relief of the region. However, erosion takes place mainly due the following processes: hydraulic action, abrasion, attrition and corrosion; the first of them depends on the nature of the coast, the types of crocks, the presence of joints and fractures in the rocks, the chemical action of seawater and the strength of waves (Reddy, 2010). The spatial arrangement of the rock with respect to the slope topography also influences the alteration process. A very important factor is the action of seawater in phyllites, which accentuates the effect of jointing, foliation and banding, due to differential solubility and altered mineral composition, which is evident in some cliffs along the coastline. Lithogeomorphology focuses on the response of the rock erosion efforts, although it is not very well differented. Structural geomorphology reflects the expression of faults and some folded structures on the rocks. It is recognizable as remaining strong, triangular facets, disruption of the slope by fault chairs, a twist of watersheds resulting in fault hooks and rectilinear fault line. An additional structural control is the jointing, which allows the entry of seawater and, therefore, its action, as described in the phenomenological geomorphology. The jointing factor has also caused the differential erosion in the study area, since the density of jointing varies and, consequently, the effect of seawater is different, resulting more affected in some areas than in others. Certain landscape features are linked to the climate determining the geomorphological evolution, i.e., the climate governs the process of change because it determines the temperature and humidity for the development of soils caused by chemical alteration, mainly by solubility or hydrolysis. The vegetation, also affected by the climate, gets protection against erosion by different agents, which also promotes condensation of soluble products. One of the most prominent coastal landforms in the study area is the presence of the NW-SE striking Santa Marta stack. It is the result of the progressive refraction of waves occurring on headlands, which concentrate wave energy on them, with the formation of stacks that can be very important due to their substantial influence on the erosion-accretion effect, taking into account that they modify the wave direction and, in a way, that of the littoral drift. In metamorphic rocks such as phyllites, cliffs are convex and frequently covered with vegetation only on the top. Cliffs show steep slopes (about $15^{\circ}$ to the vertical position or even on a sheer drop), very variable in height, which have resulted from wave action. In the bottom, a rocky base with a gentle slope (abrasion platform) precedes cliffs. In the ocean-continent contact, erosion of the rocks due to wave action on phyllites has created alveolar landforms with a honeycomb structure. This happens since phyllites are composed of interbedded hard and soft material. In general, this structure developed particularly where seawater splashes after smashing against the rock. In sectors where the sea enters the continent, bays form with gentle slopes promoting the development of beaches that offer a semi-circular arc, unless they have rocky outcrops, where beaches divide into a series of secondary beaches, also arched, with the ends lying on the rocky headlands one after the other. Throughout the study area, the highest elevations are continuous and they generate blades that extend for several kilometers where tectonic stress has acted to produce folding. On their slopes, all kinds of denuded landforms occur. The vegetation partially control the strong erosion caused by steep slopes. In the bays, it is also possible to recognize some Quaternary deposits caused by rivers flowing into them and forming some valleys and floodplains. Having conducted a review of the various factors contributing to the erosion-accretion processes, such as geomorphology, there is evidence that the study area has suffered major retreats in its shoreline in recent years, although in some cases accretion processes are also present. There are several evidences of coastal erosion, which is occurring and generating strong impacts on the study area, and although its causes and consequences have become important issues in recent years, the problem has not been appropriately managed according to several authors (Jonah, et al., 2016). A strong erosion, with a greater retreat, has occurred in areas such as Los Cocos, the Simón Bolívar International Airport area and Plenomar beaches. This is mainly due to human action and coastal constructions in areas where the risk of erosive action is greater, in addition to the surge affecting these sectors and the occurrence of unconsolidated coast (very low slope). Erosion acts on a smaller scale in sectors such as consolidated beaches and coastal plains, whereas cliffs at headlands have suffered greater erosive effects because they are constantly exposed to the onslaught of the waves. We found a great similarity in floodplains such as those occurring in Pescaíto, La Escollera lagoon and Plenomar, where desiccation cracks occur, revealing this type of environment, along with their location, as they were observed in the NE flank on Punta Betín, Punta Burukuka and Punta Gloria, respectively. Pescaíto is important, as it was flooded in the past due to a rise in the sea level (hence its name "small fish"), because a lagoon environment occurred. The different geomorphological characteristics of the study area allowed dividing it into two types: very low slope and wide beach areas $(\sim 40-60 \mathrm{~m})$, which are limited to coastal and floodplains. Wave breaks on the coast, which favors the formation of beaches as has occurred on beaches in the hotel sector, the Simón Bolívar International Airport area and Santa Marta bay. Steep slope and narrow beach areas ( $10-30 \mathrm{~m}$ ) present cliffs or paleo-cliffs with or without beach surrounded by hills. Here, a sequence of fallen blocks occur on the coast as it does in Punta Gloria, Punta Gaira, Punta Burukuka and Punta Cabeza de Negro. In these areas, the 
slope of the beach profile on the coastline plays a very important role and the breaking of waves occurs farther from the coastline. This classification took into account mainly beach slopes and, consequently, the breaking of waves and its relationship with some landforms. Given that geomorphology controls the processes acting on the different geological formations, it is obvious that further erosion works in steep slope and narrow beach areas. These changes in morphology are very important because they relate directly to the hydrodynamics of the study area. For example, in Punta Burukuka, the change in drift direction is related to a structure (boardwalk) associated with the headland. The largest slopes are associated with areas of greater erosion, where the wave breaks stronger and closer to the coast producing a negative response (retreat) from the coast by the action of waves. Regarding the relationship between the sedimentary characteristics and recognizable erosion, there are two main sources of sediments: the contribution by the Manzanares and Gaira rivers and that caused by the erosion of cliffs. The sediment transport is mainly by rivers, coupled with transport by drift currents. The characteristics of beach sands, such as composition, grain size and sorting, suggest high sediment reworking of fluvial origin before reaching the beach. This may be because the sediment source areas are far from the final deposition area. Analyses of beach sediments have revealed similar compositional characteristics to those in rocks found on cliffs occurring in outgoings, with variations in grain size, distribution and roundness that suggest a minor rework and transport from their source area. There is no doubt that the several coastal landforms that comprise the study area are the result of a dynamic interaction among several factors. According to Burkett \& Davidson (2012), these factors include: 1) physical processes that act on the coast such as storms, waves, currents, sand sources and sinks and relative sea level; 2) human activity such as dredging, dams, and coastal engineering, and 3) the geological character of the coast and nearshore. During the last 50 years, the main causes of erosion-accretion processes in the study area have involved both anthropogenic and natural factors. The lack of clearly defined policies on coastal zone management has deepened the impact of these factors, and the problem is worse if we consider the little data available on shoreline changes along Caribbean coasts. According to Pethick \& Crooks (2000), with the growing need to carry out the sustainable coastal resource management beyond shoreline management, there is an emerging understanding to manage the resulting changes that will accompany global warming, rather than trying to maintain a fossilized and inevitably progressively degraded coastal system.

\section{Conclusions}

The results of the present study are a contribution to geological knowledge of the GPSM, and are intended to promote research in the Caribbean coast on the increasing marine activity, the growing population driven to the coast, the strengthening of tourism in the localities in the study area, and a series of geological evolutionary processes reflecting on coastal morphology. We identified and characterized several coastal landforms resulting from deposition and erosion processes, which manifest in the presence of bays and headlands generating a variety of landforms that give a great view of the landscape. However, the geomorphology observed in the study area is the result of several phenomena (waves, currents, tides, sediment download, runoff, landslides movements and changes in the landscape due to human action). We also determined coastline variations of the GPSM between Punta Brava and Punta Betín for the 1854-2006 period. We concluded that the study of coastal geomorphology represents a sound basis for developing overall strategies, policies and criteria to correct existing situations and encourage environmentally balanced land use plans for the coastal region between Punta Brava and Punta Betín based on the protection of its natural environment from serious or irreversible damage. It is necessary to increase research in the study area for a better understanding of its climatic, hydrodynamical, geological and geomorphological conditions, among others, which will provide more and better solutions to problems generated in the study area. Future research should identify the relationship of climatic variations occurring in the recent past and the morphodynamical processes that have affected the coast. On the other hand, it is necessary to determine the influence of climatic change and other factors as the surf, along with the corresponding morphodynamical changes on coastal ecosystems and human activities.

\section{Supplementary information}

Figure 1S. Geological and structural map of the coastline between Punta Brava and Punta Betín. Adapted and modified from Vargas (2006). See Supplemental figure in: http://www.raccefyn.co/index. php/raccefyn/article/downloadSuppFile/387/1581

Figure 2S. Field photographs of the main lithological features observed in the study area. See Supplemental figure in: http://www raccefyn.co/index.php/raccefyn/article/downloadSuppFile/387/1582 Figure 3S. Conceptual diagram of erosion and accretion trends and inferred net sediment transport for the study area (adaptated from Romine, et al., 2016). See Supplemental figure in: http://www. raccefyn.co/index.php/raccefyn/article/downloadSuppFile/387/1753 Figure 4S. Shoreline variation since 1954 for the study area derived from historical aerial photographs. See Supplemental figure in: http://www.raccefyn.co/index.php/raccefyn/article/download SuppFile/ 387/1754

\section{Acknowledgments}

This research is part of the undergraduate thesis of V. Vargas. The authors are grateful to the Instituto de Investigaciones Marinas y Costeras "José Benito Vives de Andreis" (INVEMAR) and the Universidad Industrial de Santander, 
and it has benefited from research facilities provided by these institutions. Authors thank G. Guzmán, B. Posada and $\mathrm{N}$. Rangel for their valuable help and support, as well as the reviewers of this paper for their constructive comments and valuable suggestions, which greatly improved the quality of the manuscript.

\section{Conflicts of interest}

The authors declare that they have no conflict of interest.

\section{References}

Aiello, A., Canora, F., Pasquariello, G., Spilotro, G. (2013). Shoreline variations and coastal dynamics: A spaceetime data analysis of the Jonian littoral, Italy. Estuarine, Coastal and Shelf Science. 129: 124-135.

Almonacid-Caballer, J., Sánchez-García, E., Pardo-Pascual, J.E., Balaguer-Beser, A.A., Palomar-Vázquez, J. (2016). Evaluation of annual mean shoreline position deduced from Landsat imagery as a mid-term coastal evolution indicator. Marine Geology. 372: 79-88.

Aristizábal, O., Betancur, J., Vásquez, C. (1990). Erosión y sedimentación de la línea de costa entre Turbo y Necoclí, Golfo de Urabá. Undergraduate Thesis, Universidad EAFIT, Medellín, Colombia.

Bernal, G., Montoya, L.J., Garizábal, C., Toro, M. (2005). La complejidad de la dimensión física en la problemática costeras del Golfo de Urabá, Colombia. Gestión y Ambiente. 8 (1): 123-135.

Botero, L., Mancera, J.E. (1996). Síntesis de los cambios de origen antrópico ocurridos en los últimos 40 años en la Ciénaga de Santa Marta (Colombia). Revista Academia Colombiana de Ciencias. 20: 465-474.

Briceño, L.A. \& Vernette, G. (1992). Manifestaciones del diapirismo de lodo en el margen colombiano del Caribe. Geofísica Colombiana. 1: 21-30.

Burkett, V. \& Davidson, M. (2012). Coastal Impacts, Adaptation, and Vulnerabilities: A Technical Input to the 2012 National Climate Assessment. Island Press, London (England).

Campbell, C.J. (1965). The Santa Marta wrench fault of Colombia and its regional setting. In: Saunders, J.B. (Editors.). Transactions of the Fourth Caribbean Geological Conference. Port-of-Spain. p. 247-262.

Cardona, A., Cordani, U.G., MacDonald, W.D. (2006). Tectonic correlations of pre-Mesozoic crust from the northern termination of the Colombian Andes, Caribbean region. Journal of South American Earth Sciences. 21: 337-354.

Cardona, A., Valencia, V., Bustamante, C., García-Casco, A., Ojeda, G., Ruiz, J., Saldarriaga, M., Weber, M. (2010). Tectono-magmatic setting and provenance of the Santa Marta Schists, northern Colombia: Insights on the growth and approach of Cretaceous Caribbean oceanic terranes to the South American continent. Journal of South American Earth Sciences. 29: 784-804.

Church, J.A. \& White, N.J. (2011). Sea-level rise from the late 19 th to the early 21 st century. Surveys in Geophysics. 32 (4-5): 585-602.

Church, J.A., White, N.J., Konikow, L.F., Domingues, C.M., Cogley, J.G., Rignot, E., Gregory, J. M., Van den Broeke, M.R., Monaghan, A.J., Velicogna, I. (2011). Revisiting the Earth's sea level and energy budgets from 1961 to 2008. Geophysical Research Letters, 38 (18): 1-8.
Cooper, J.A.G. \& McLaughlin, S. (1998). Contemporary multidisciplinary approaches to coastal classification and environmental risk analysis. Journal of Coastal Research. 14 (2): 512-524.

Cordani, U., Cardona, A., Jiménez, D., Liu, D., Nutman, A. (2005). Geochronology of Proterozoic basement inliers in Colombian Andes: Tectonic history of remnants of a fragmented Greenville belt. In: Vaughan, A., Leat, P., Pankhurst, R. (Editors). Terrane processes at margins of Gondwana. Geological Society, London, Special Publications. 246: 329-346.

Correa, I.D. (1990). Inventario de erosión y acreción litoral entre Los Morros y Galerazamba, Departamento de Bolívar, Colombia. En: Hermelin, M. (Editores.) Association of Geoscientists for International Development (AGID). Technical Report. 13: 129-142.

Correa, I.D. \& Vernette, G. (2004). Introducción al problema de la erosión litoral en Urabá (sector Arboletes - Turbo), costa Caribe colombiana. Boletín de Investigaciones Marinas y Costeras. 33 (1): 7-28.

Correa, I.D., Alcántara-Carrió, J., González, D.A. (2005). Historical and recent shore erosion along the Colombian Caribbean coast. Journal of Coastal Research. Special Issue. 49: 52-57.

Correa, I.D., Ríos, A., González, D.A., Toro, M., Ojeda, G., Restrepo, I. (2007). Erosión del litoral entre Arboletes y Punta San Bernardo, costa Caribe colombiana. Boletín de Geología. 29 (2): 115-129.

Crooks, S. (2004). The effect of sea-level rise on coastal geomorphology. Ibis. 146 (1): 18-20.

Davidson-Arnott, R. (2010). An Introduction to Coastal Processes and Geomorphology. Cambridge University Press, New York.

Davies, J.L. (1977). Geographical Variation in Coastline Development. Longman, New York.

Davis, R.A. (2012). Coastal Sedimentary Environments. Springer Science \& Business Media, New York.

Delgado, R. (2002). Evaluación de la estabilidad de la franja costera del departamento del Magdalena en términos de erosión y sedimentación. Tesis, Universidad Nacional de Colombia, Bogotá (Colombia).

Díaz, J.M., Sánchez, J.A., Díaz, G. (1996). Geomorfología y formaciones arrecifales recientes de isla Fuerte y Bajo Bushnell, plataforma continental del Caribe colombiano. Boletín de Investigaciones Marinas y Costeras. 25: 87-105.

Doolan, B.L. (1970). The structure and metamorphism of the Santa Marta área, Colombia, South America. PhD Thesis, New York State University, New York (USA).

Donoso, M.C. (1990). Circulación de las aguas en el mar Caribe. Seminario Nacional de Ciencias y Tecnologías del Mar (Memorias), Comisión Colombiana de Oceanografía, Santiago de Cali. p. 345-356.

Duque-Caro, H. (1980). Geotectónica y evolución de la región noroccidental colombiana. Boletín Geológio Ingeominas. 23 (3): 4-37.

Duque-Caro, H. (1984). Estilo estructural, diapirismo y episodios de acrecimiento del terreno Sinú - San Jacinto en el noroccidente de Colombia. Boletín Geológio Ingeominas. 27 (2): 1-29.

Earle, S. (2015). Physical Geology. BCcampus OpenEd, Vancouver. Fairbridge, R.W. (2004). Classification of coasts. Journal of Coastal Research. 20: 155-165. 
Finkl, C.W. (2004). Coastal classification: Systematic approaches to consider in the development of a comprehensive scheme. Journal of Coastal Research. 20: 166-213.

Franco, J.V. (1990). Efecto de los fenómenos meteorológicos en la dinámica de las playas de Cartagena (Julio 1987 Diciembre 1989). VIII Seminario Nacional de Ciencias y Tecnologías del Mar (Memorias), Comisión Colombiana de Oceanografía, Santiago de Cali. p. 132-140.

Franco, E. \& Gómez, J.F. (1996). Evolución de la Línea de Costa del Litoral Antioqueño. Aspectos Geomorfológicos, Sector Río Necoclí - Turbo. Tesis. Universidad Nacional de Colombia, Medellín, Colombia.

Garay, J.A., Marín, B., Ramírez, G., Betancourt, J., Troncoso, W., Gómez, M.I., Cadavid, B., Vélez, A.M., Rozo, D., Lozano, P., Casas, M., Arias, L., Vivas, L.J. (2002). Diagnóstico y evaluación de la calidad ambiental marina en el Caribe y Pacifico colombiano, Red de vigilancia para la protección y conservación de la calidad de las aguas marinas y costeras, Instituto de Investigaciones Marinas y Costeras. p. 260.

Google Earth. (Please cite specific section accessed) Available from: http://earth.google.com. Accessed on: May 8, 2014.

Idárraga, J., Posada, B.O., Guzman, G. (2011). Geomorfología de la zona costera adyacente al piedemonte occidental de la Sierra Nevada de Santa Marta entre los sectores de Pozos Colorados y el río Córdoba, Caribe colombiano. Boletín de Investigaciones Marinas y Costeras. 40 (1): 41-58.

INVEMAR (2004). Definición de la vulnerabilidad de los sistemas bio-geofísicos y socioeconómicos debido a un cambio en el nivel del mar en la zona costera colombiana (Caribe continental, Caribe insular y Pacífico) y medidas para su adaptación. Informe Técnico No. 2: Caracterización e Inventario. p. 40-44.

Irving, E.M. (1971). Structural evolution of the northernmost Andes, Colombia. USGS Professional Paper. Washington DC. p. 27.

Jonah, F.E., Boateng, I., Osman, A., Shimba, M.J., Mensah, E.A., Adu-Boahen, K., Chuku, E.O., Effah, E. (2016). Shoreline change analysis using end point rate and net shoreline movement statistics: An application to Elmina, Cape Coast and Moree section of Ghana's coast. Regional Studies in Marine Science. 7: 19-31.

Kellogg, J. (1984). Cenozoic and tectonic history of the Sierra de Perijá, Venezuela-Colombia, and adjacent basins. GSA Memoir. 162: 239-261.

Lalbiakzuali, C., Suresh-Gandhi, M., Ram-Mohan, V. (2013). Geomorphology and evolution of coastal landforms between Mimisal and Rajamadam, Palk Strait, east coast of India. Current Science. 105 (12): 1730-1735.

MacDonald, W.D., Doolan, B.L., Cordani, U.G. (1971). Cretaceous - Early Tertiary metamorphic K-Ar age values from the South Caribbean. Geological Society of America Bulletin. 82: 1381-1388.

Magbagbeola, F.A. (2011). The coast and its associated landforms. Bachelor of Technology Thesis. Federal University of Technology, Akure (Nigeria).

Martínez, E. (1989). Evolución de los sectores del Laguito y Bocagrande en Cartagena. Bulletin de l'Institut de Géologie du Bassin d'Aquitaine. 45: 189-195.

Martínez, J.O. (1993). Geomorfología y amenazas geológicas de la línea de costa del Caribe central colombiano (Sector Cartagena - Bocas de Ceniza). Publicaciones Geológicas Especiales Ingeominas. 19: 1-62.
McFadden, L., Nicholls R.J., Penning-Rowsell, E. (2007). Managing Coastal Vulnerability, Elsevier, Oxford.

Mejía, H.P., Santa, E.M., Ordóñez-Cardona, O., Pimentel, M. (2008). Consideraciones petrográficas, geoquímicas y geocronológícas de la parte occidental del batolito de Santa Marta. DYNA. 75 (155): 223-236.

Mohanty, P.K., Barik, Sh.K., Kar, P.K., Behera, B., Mishra, P. (2015). Impacts of ports on shoreline change along Odisha coast. Procedia Engineering. 116: 647-654.

Molina, A., Molina, C., Chevillot, P. (1992). La percepción remota aplicada para determinar la circulación de las aguas superficiales del Golfo de Urabá y las variaciones de su línea de costa. Boletín Científico CIOH. 11: 43-58.

Montes, C., Guzmán, G., Bayona, G., Cardona, A., Valencia, V., Jaramillo, C. (2010). Clockwise rotation of the Santa Marta massif and simultaneous Paleogene to Neogene deformation of the Plato-San Jorge and Cesar-Ranchería basins. Journal of South American Earth Sciences. 29 (4): 832-848.

Morton, R. \& Correa, I.D. (2004). Introducción al uso de los geoindicadores de cambios ambientales en costas húmedas tropicales. Geología Norandina. 12 (1): 1-15.

Nagle, G. (2000). Advanced Geography. Oxford University Press, Oxford.

Ordóñez, C. (2002). Dinámica de la línea de costa, por erosión y sedimentación, del tramo entre playa de los Holandeses y punta Chuchupa, departamento de La Guajira. Undergraduate Thesis, Universidad Nacional de Colombia, Bogotá Colombia.

Ordóñez-Cardona, O., Pimentel, M.M., De Moraes, R. (2002). Granulitas de Los Mangos: un fragmento grenviliano en la parte SE de la Sierra Nevada de Santa Marta. Revista Academia Colombiana de Ciencias. 26: 169-179.

Pethick, J.S. \& Crooks, S. (2000). Development of a coastal vulnerability index: A geomorphological perspective. Environmental Conservation. 27: 359-367.

Posada, B.O. \& Henao, W. (2008). Diagnóstico de la erosión en la zona costera del Caribe colombiano. INVEMAR, Serie Publicaciones Especiales No. 13, Santa Marta, p. 200.

Prasita, V.D. (2015). Determination of shoreline changes from 2002 to 2014 in The Mangrove Conservation Areas of Pamurbaya using GIS. Procedia Earth and Planetary Science. 14: 25-32.

Raasveld, R.H. \& Tomic, A. (1958). Lagunas colombianas. Revista de la Academia Colombiana de Ciencias Exactas, Físicas y Naturales. 40: 175-198.

Radelli, L. (1962). Introducción al estudio de la geología y de la petrología del Macizo de Santa Marta (MagdalenaColombia). Geología Colombiana. 2: 41-115.

Rangel-Buitrago, N. (2009a). Geomorfología y cambios de la línea de costa entre el cabo San Juan de Guía y el río Cañas (Departamentos del Magdalena y La Guajira). MSc Thesis. Universidad EAFIT, Medellín (Colombia).

Rangel-Buitrago, N.G. (2009b). Contribución antropogénica a los cambios geomorfológicos y evolución reciente de la costa Caribe colombiana. Revista Gestión y Ambiente. 12 (2): 43-56.

Rangel-Buitrago, N.G. \& Posada-Posada, B.O. (2005). Geomorfología y procesos erosivos en la costa norte del departamento de Córdoba, Caribe colombiano (Sector Paso Nuevo-Cristo Rey). Boletín de Investigaciones Marinas y Costeras. 34 (1): 101-119. 
Rangel-Buitrago, N.G. \& Anfuso, G. (2013). Morfología, morfodinámica y evolución reciente en la Península de la Guajira, Caribe colombiano. Revista Ciencias e Ingeniería al Día. 8 (1): 7-24.

Ramírez, J.E. (1959). El volcán de lodo de Galerazamba. Revista de la Academia Colombiana de Ciencias Exactas, Físicas y Naturales. 41: 301-314.

Reddy, D.V. (2010). Engineering Geology. Vikas Publishing House PVT LTD, New Dehli (India).

Restrepo, J.C. (2001). Geomorfología y análisis de las variaciones de la línea de costa de la zona norte del golfo de Morrosquillo y el archipiélago de islas de San Bernardo, Caribe colombiano. Una contribución a la formulación del Plan de Manejo Integrado de la Unidad Ambiental Costera Río SinúGolfo de Morrosquillo. Undergraduate Thesis, Universidad de Caldas, Manizales (Colombia).

Restrepo, J.D. \& Kjerfve, B. (2000). Magdalena River: Interannual variability (1975-1995) and revised water discharge and sediment load estimates. Journal of Hydrology. 235: 137-149.

Restrepo-Pace, P.A., Ruiz, J., Gehrels, G., Cosca, M. (1977). Geochronology and $\mathrm{Nd}$ isotopic data of Grenville-age rocks in the Colombian Andes: New constraints for late Proterozoic - early Paleozoic paleocontinental reconstructions of the Americas. Earth and Planetary Science Letters. 150: 427-441.

Romine, B.M., Fletcher, C.H., Frazer, L.N., Anderson, T.R. (2016). Beach erosion under rising sea level modulated by coastal geomorphology and sediment availability on carbonate reef-fringed island coasts. Sedimentology. 63 (5): 1321-1332.

Serrano, B.E. (2004). The Sinú River delta on the northwestern Caribbean coast of Colombia: Bay infilling associated with delta development. Journal of South American Earth Sciences. 16: 623-631.

Velásquez, C. \& Rave, J. (1996). Dinámica costera y geomorfología en el Golfo de Urabá antioqueño. Sector Boca Tarena - Espiga de Turbo. Undergraduate Thesis, Universidad Nacional de Colombia, Medellín (Colombia).
Shipman, H. (2008). A geomorphic classification of Puget Sound nearshore landforms. Puget Sound Nearshore Partnership Report No. 2008-01. Published by Seattle District, U.S. Army Corps of Engineers, Seattle, Washington. Available from: www.pugetsoundnearshore.org. Accessed on: 25 May, 2015

Suzunaga, J.O., Molina, A., Pelgrain, A., Parra, C. (1990). Estudio de la oceanografía costera de la región de Cartagena y sus alrededores aplicando la percepción remota. Centro de Investigaciones Oceanográficas e Hidrográficas, Misión Técnica Francesa, Cartagena de Indias. p. 84.

The Gateway to Astronaut Photography of Earth. Image Science and Analysis Laboratory, NASA-Johnson Space Center. Available from: http://earth.jsc.nasa.gov/sseop/EF/ photoinfo.p?PHOTO=STS032-71-39. Accessed on: July 5, 2015.

Tschanz, C.M., Jimeno, A., Vesga, C. (1969). Geology of the Sierra Nevada de Santa Marta area (Colombia). Instituto de Investigaciones e Información Geocientífica, MineroAmbiental y Nuclear, República de Colombia. p. 288.

Tschanz, C.M., Marvin, R.F., Cruz, J., Mehnert, H.H., Cebula, G.T. (1974). Geologic evolution of the Sierra Nevada de Santa Marta, northeastern Colombia. Geological Society of America Bulletin. 85: 273-284.

Vargas, V.H. (2006). Estudio geomorfológico para la determinación de la variación de la línea de costa en la región costera comprendida entre Punta Brava y Punta Betín, Provincia Geotectónica de Santa Marta. Undergraduate Thesis, Universidad Industrial de Santander, Bucaramanga (Colombia).

Velásquez, N. (2000). Geomorfología y dinámica en el Urabá chocoano. Sector: Cabo Tiburón - Bahía Acandí. Undergraduate Thesis, Universidad Nacional de Colombia, Medellín (Colombia).

Williams, S.J. (2013). Sea-level rise implications for coastal regions. In: Brock, J.C., Barras, J.A. \& Williams, S.J. (Editors). Understanding and predicting change in the coastal ecosystems of the northern Gulf of México. Journal of Coastal Research. Special Issue, 63: 184-196. 